\title{
THE INFLUENCE OF INFORMATION TECHNOLOGY ON MARKETING PERFORMANCES OF TOURIST AGENCIES
}

\author{
Katarina Borisavljevic* \\ University of Kragujevac, Faculty of Economics, Kragujevac, The Republic of Serbia
}

The implementation of information technology in tourism brings numerous advantages for all participants in the chain of the tourism offer. Traditional tourist agencies also orient themselves towards online business doing via the Internet. On the other hand, the Internet has an influence on the reduction in the mediation role of tourist agencies. The subject matter of the research done in this paper is the implementation of the Internet in the business doing of tourist agencies with the aim to improve their marketing performances. The aim of the research is the influence of the quality of the Internet offer of tourist agencies on the development of the relationships with buyers and the improvement of the image of tourist agencies operating in The Republic of Serbia. The research results presented in the paper have shown that a higher level of the quality of agencies' Internet offer has a positive influence on buyer loyalty, as well as on the image of an agency. The business success of tourist agencies is based on a combined approach of traditional and online business doing.

Keywords: tourist agency, Internet, business image, buyer loyalty

JEL Classification: M15, M31, Z30

\section{INTRODUCTION}

The efficient management of the relationships between the entities in the tourism chain of the offer is conducted by applying information technology (hereinafter referred to as IT). Via the Internet, providers of tourism services (e.g. airline companies or hotels) provide intermediaries (tourist agencies) or the end users of tourism services with useful pieces of information about the offer and sale of services. During the 1960s, the Computer Reservation System - CRS,

Correspondence to: K. Borisavljevic, University of Kragujevac, Faculty of Economics, Dj. Pucara 3, 34000 Kragujevac, The Republic of Serbia; e-mail: katarinab@kg.ac.rs which was in the function of forming the bases of data in the Airline Sector, was introduced (Radosavljević, 2009, 321). Via this system, airline companies were managing their electronic reservations and forwarding them to their remote branches, tourism intermediaries and passengers. That enabled agencies, too, to make reservations more simply, operate more flexibly and cooperate with service providers. Later, by the introduction of the Global Distribution System (GDS) during the 1980s, electronic tourism (i.e. e-tourism) began to develop at a more intensive pace.

The relevant literature states both advantages and disadvantages of the implementation of IT in tourism. 
According to K. Nusair $(2008,9)$, the key advantages of IT implementation for enterprises operating in tourism are as follows: global connecting, monitoring the Internet processes and competitors' activities, adapting services to the user's needs, increasing the online user loyalty and so forth. On the other hand, IT implementation in tourism enables service users: interactivity, flexibility, the simplicity of executing transactions, a larger possibility of making a choice of tourism offers, the availability of information and so on. R. Elliot and C. Boshoff (2005), however, also point out the limitations of the implementation of electronic tourism in small and medium-sized enterprises; small and medium-sized enterprises' limited opportunities for entering the electronic market; a lack of an efficient Internet bandwidth since enterprises need to additionally pay for doing a quicker Internet search so as to avoid congestion in online business doing and so on.

The subject matter of the research conducted in this paper is the implementation of the Internet in the business doing of tourist agencies with the aim to improve their marketing performances. The aim of the research is to determine the degree of the influence of the quality of tourist agencies' Internet offer on the development of the relationships with buyers and the improvement of the image of tourist agencies operating in the Republic of Serbia (RS). The basic assumption which the paper starts from is the influence of the Internet offer of tourist agencies on increasing the degree of service user loyalty, i.e. the user's decision to recommend an agency's services to others and use the services provided by the same agency again. By applying binary logistic regression, the validity of the initial assumptions in the paper has been tested.

In the first part of the paper, the significance of the implementation of the Internet in the business operations of tourism enterprises and the ways of providing online services to end users in indicated. In the second part of the paper, the characteristics of tourist agencies' online services, as well as the relationship between traditional agencies doing business via the Internet and virtual agencies, are discussed. The third part of the paper is dedicated to research into the influence of the quality of tourist agencies' websites on their marketing performances.

\section{THE IMPLEMENTATION OF THE INTERNET IN ENTERPRISES OPERATING IN TOURISM}

The implementation of the Internet as a marketing instrument in enterprises operating in tourism enables cost savings, the quickness in the execution of transactions, the availability of information, efficient communication, comfortability while purchasing, the implementation of target marketing, the entrance of small enterprises into the international tourism market and the development of relationships with buyers (Elliott \& Boshoff, 2009).

The implementation of the Internet in tourism business doing is based on a resource-based approach. Successful resource management (of technical, information, human and other resources) contributes to the achievement of the comparative advantage of enterprises operating in tourism. The implementation of the Internet, the GPS or mobile phones has an influence on the creation of a positive impression and experience with tourists. Travelers use the GPS with the aim to find the desired tourism destinations more simply and more quickly. Airliners offer passengers online reservations via mobile implementations and enable electronic checking at airports (e-boarding passes), which enhances the comfortability of traveling, reduces operating costs as well as the number of the employed, since sale is done exclusively via electronic kiosks (Yoo, Lee \& Park, 2010). For example, the implementation of new technological implementations in hotels offers a better control of costs, the more efficient implementation of marketing strategies and information flows, the simplicity and comfortability of online purchase, the availability of the service $24 \mathrm{~h} 365$ days in the year and so forth. According to A. Bilgihan, F. Okumus, K. Nusair and D. Kwun $(2011,140)$, the successfulness of the implementation of technological implementations in enterprises operating in tourism will depend on the following: the alignment of the business strategy with the implementation of IT solutions; the types of IT implementations; the possibilities of applying IT; the available financial means, and the manner in 
which decisions are made in hotels as well as in other enterprises operating in the field of tourism.

In the budget hotels and economic types of hotels, IT is applied with the aim to increase operating efficiency, whereas in luxury hotels, the introduction of technological innovations contributes to the improvement of the quality of the accommodation offer. According to the data of the American Society of Travel Agents from 2003, over 64 million citizens used the Internet with the aim to search destinations, compare prices of tourism offers or airline tickets. Out of the total number of the citizens who used the Internet, almost 42 million booked their travels via the Internet (Nusair, 2008, 21). Starting from the significance of IT in tourism, the paper analyzes the quality of the Internet offer and its influence on an increase in client loyalty towards the tourist agencies operating in RS.

The Internet has led to the transformation of certain elements of the traditional concept of the marketing mix. In that context, the so-called "dynamic package" in tourism (Middletion, Fayll \& Morgan, 2009, 268) stands for a replacement for the tourist product because it offers a more flexible and faster system of reservations for passengers, enables mass customization and adaptation to individual users' needs. The tourist agencies that cooperate with the so-called "banks offering accommodation services" (bad banks) offer lower prices for hotel services in comparison with other agencies. Apart from the online transparency of the prices stipulated in offers, the travelers also have a possibility of choosing the date of travel, the type of the transportation means, the type of accommodation via the Internet and so on. Online distribution includes online reservation and additional contents of the destination offer, such as social attractions or optional outings, simultaneously enabling clients not to queue at agencies' branch offices. The sale of arrangements via online distribution channels enables tourism enterprises to appear on the foreign market. Online promotion is conducted via the website, and the quality of the website plays a particularly significant role in increasing the level of online user loyalty, which on its part is the subject matter of the research conducted in this paper.

Internet business operations can be performed through the reservation systems, virtual or online agencies
(Expedia), search engines (Google, Kayak), social networks, web-portals (Tripadvisor), websites for comparing prices for different package arrangements (Kelkoo) and tourism bidders' or intermediaries' websites (Buhalis \& Law, 2009). K. Nusair (2008) demonstrated different manners of providing online services to end users in Table 1.

On the basis of the Table 1, a conclusion can be drawn that there are enterprises that offer different manners in which the online sale of tourism arrangements is conducted. Online agencies sell services of accommodation, transportation, rent-a-car and so forth provided by several bidders. Tourism enterprises can sell their own arrangements via their websites or hyperlinks, on the basis of which users search tourism offers.

There is a difference in prices in the sale of package arrangements or airline tickets of traditional and virtual agencies. Namely, they are lower in the tourism offer of virtual agencies (Ngai, 2005). As far as airline tickets are concerned, travelers search for more favorable ticket prices via the Internet, which increases the comfortability of buying and the degree of the competitiveness in the online environment. Global virtual agencies (e.g. Expedia, Orbitz, Lastminute.com, Opodo, Travelocity etc.) provide clients a possibility of buying in a single place (one-stop shopping) via the interactive website, which is an advantage in comparison with traditional tourist agencies. Search for information and giving recommendations via the Internet, as well as the online complaint management process, can have a positive influence on agencies' image, too. Also, with the aim to minimize insecurity while buying online, users have ever-increasingly been relying on other online users' recommendations (Thao \& Swierczek, 2008). According to the results of a research study (according to Liu \& Park, 2015), 83\% of international tourists use the Internet in the phase of planning a journey, while simultaneously $43 \%$ of them rely on other tourists' online comments and recommendations.

\section{TOURIST AGENCIES' INTERNET OFFER}

The implementation of Information Technology in tourism leads to a reduction in the costs of business operations and the elimination of intermediaries' role 
in marketing channels (Álvarez et al, 2007). Many tourism services providers register their own online agencies. Tour operators can place their offers through their online portals. Independent virtual agencies (e.g. Lastminute.com, Booking.com, Expedia etc.) are becoming the major competitors to traditional agencies. Also, traditional business doing of agencies is also influenced by low cost companies because they mainly provide more favorable intermediation services than agencies do (e.g. information-advisory and promotion-sale activities), such as: car renting services, hotel accommodation, insurance services etc. (Mamaghani, 2009).

The implementation of the Internet in tourism, however, offers a possibility for tourist agencies to orient themselves towards online sale as well. In that context, they provide individual services and special treatments, which is also going to indirectly lead to an increase in traditional buying, i.e. to an increase in the number of clients visiting the agency in person (Álvarez, 2007). On the other hand, the Internet has an influence on a reduction in agencies' intermediation role. Agencies will, however, keep on maintaining their dominant role on the foreign and domestic tourism markets since buyers will still be relying on their professional services related to the provision of information, journey planning and booking (Unković and Zečević, 2013, 95). This is for the reason of the fact that there will be a decrease in the uncertainty of online sale and an increase in the level of user trust in a particular tourist agency.

Table 1 Ways of online business doing

\begin{tabular}{|c|c|c|}
\hline Retailers & Description of Business & Example \\
\hline Online agencies & $\begin{array}{l}\text { The sale of different types of tourist products } \\
\text { by several bidders. Tourist products include } \\
\text { services of airline transportation, hotels, rent- } \\
\text { a-car, cruisers etc. }\end{array}$ & $\begin{array}{l}\text { www.travelocity.com } \\
\text { www.expedia.com } \\
\text { www.orbitz.com }\end{array}$ \\
\hline $\begin{array}{l}\text { Service providers' } \\
\text { websites }\end{array}$ & $\begin{array}{l}\text { The sale of own package arrangements via } \\
\text { the Internet or through business partners. }\end{array}$ & $\begin{array}{l}\text { www.Starwood.com } \\
\text { www.AA.com }\end{array}$ \\
\hline Auctions & $\begin{array}{l}\text { The portals offering booking possibilities } \\
\text { within the tourism section. Booking requests } \\
\text { are filled in in compliance with an agreement } \\
\text { with agencies. Yahoo uses Travelocity } \\
\text { reservation capacities. }\end{array}$ & www.yahoo.com \\
\hline Search Engines & $\begin{array}{l}\text { Buyers search products by entering the key } \\
\text { word and via hyperlinks of tourism bidders, a } \\
\text { particular offer can be chosen. }\end{array}$ & $\begin{array}{l}\text { www.gooogle.com } \\
\text { www.travelzoo.com } \\
\text { www.overture.com }\end{array}$ \\
\hline Shopping bidders & $\begin{array}{l}\text { They offer bidders' websites and present total } \\
\text { search results. }\end{array}$ & $\begin{array}{l}\text { www.kayak.com } \\
\text { www.sidestep.com }\end{array}$ \\
\hline $\begin{array}{l}\text { Reverse auction } \\
\text { websites }\end{array}$ & $\begin{array}{l}\text { Buyers make certain requests for desired } \\
\text { attributes of products, the price and other } \\
\text { conditions, whereas the website searches the } \\
\text { bidders who will fulfil the requested or preset } \\
\text { conditions. }\end{array}$ & www.priceline.com \\
\hline
\end{tabular}


The characteristics of online services are a high degree of the differentiation and intangibility of the offer, as well as the low degree of client participation in creating package arrangements (Chiam, Soutar \& Yeo, 2009). The research study has shown that around $95 \%$ of tourists in the world obtain information via the Internet, about $93 \%$ of tourists visit websites with the aim to search tourism destinations, whereas around $45 \%$ of them contact tourist agencies by email with the aim to obtain additional pieces of information and useful pieces of advice (Mamaghani, 2009, 365). This is yet another proof that agencies should be doing their business via the Internet, as well as within the premises of their traditional business units. As M. Mamaghani (2009) states, there are different client profiles when opting for a tourism arrangement. One group of clients will wish to buy the total tourism offer, namely "purchase in a single place", whereas the other will wish to independently create an arrangement in compliance with their preferences.

Tourist agencies have ever-increasingly been developing their online relationships with service providers (e.g. hotels, airline companies etc.) and service users. According to the data obtained from the Center for Market Information Provision (Agag \& elMasry, 2016), the sale of tourist journeys has achieved the greatest participation (48.9\%) in the total sale of online products and services. In the period from 2011 to 2014, there was an increase in the sale of online tourism offers by $10 \%$ on the international market, whereas by the end of 2016, the annual rate of online tourism arrangements will have amounted to $8 \%$.

With the aim to analyze the level of the implementation of electronic business operations in tourist agencies in $\mathrm{RS}$, a research study was conducted on the territories of major cities/towns (Radosavljević, Maksimović \& Borisavljević, 2012). On the basis of the structured questionnaire, the managers of 62 tourist agencies operating in Serbia were subjected to an in-person interview. On the basis of the collected data, we became aware of the fact that about $15 \%$ of the tourist agencies offered their package arrangements exclusively via the Internet, whereas the other agencies sold their package arrangements in a traditional and electronic way. The research study also showed that the agencies used the mail and the telephone for the most part with the aim to build and maintain their relationships with their business partners and clients. Besides, they used the fax, catalogues or websites. The research results also revealed that there were a large number of the factors that had an influence on the implementation of the Internet in the business operations conducted by the tourist agencies. Agencies' employees' and clients' requests have, to the greatest extent, an influence on the implementation of the Internet in agencies' business operations (over $50 \%$ ), which is also followed by their business partners' requests and the influence coming from their competitors (approximately 20\%). On the basis of the mentioned research results, a conclusion can be drawn that Serbian tourist agencies apply traditional and electronic ways in their respective communication with their partners (hotels, airline companies etc.) and clients. Similarly to the mentioned results, there are also the other authors (Mihajlović, 2012) who conclude that the implementation of the Internet in tourist agencies' business doing cannot replace the traditional activities based on the establishment of a personal contact with clients, as a precondition for enhancing their loyalty. The Internet also offers users a possibility of moving on to another bidder or comparing the prices of competitive offers with "only a few clicks with the mouse" as well, which has a negative influence on the maintenance of longterm relationships between the online user and tourist agencies.

In less developed countries, clients rather prefer buying their tourism arrangement by paying a visit to a local tourist agency and establishing a personal contact with the agency's personnel. For that reason, the traditional way of sale combined with tourist agencies' online sale has for the most part an influence on the development of client relationships.

In the analysis of the influence of the implementation of the Internet in tourist agencies on an increase in online user satisfaction and loyalty enhancement, the following initial dimensions of the quality of online services are as follows: the knowledge of information, the security and functionality of the website, which are only followed by relationships with users, providing individual services, interactive communication, as well as the rate of responding to users' individual requests. The quality level of agencies' tourism offer 
has a significant influence on the degree of the user's e-satisfaction and e-loyalty (Ho \& Lee, 2007).

In the analysis of the development of online relationships with buyers in agencies, M. Chen and Y. Kao (2010) have identified the two key dimensions of the online service quality: the quality of the process and the quality of the service. The quality of the process is analyzed on the basis of the simplicity of use, good layout and functionality of the website, on the basis of its ability to provide correct and precise pieces of information, as well as on the basis of the website's design, which has a positive influence on online clients' satisfaction and loyalty. The quality of the process is measured on the basis of the analysis of the interaction between visitors and the website, which will have a positive reflection on the perceived level of the total quality of online services and user online satisfaction.

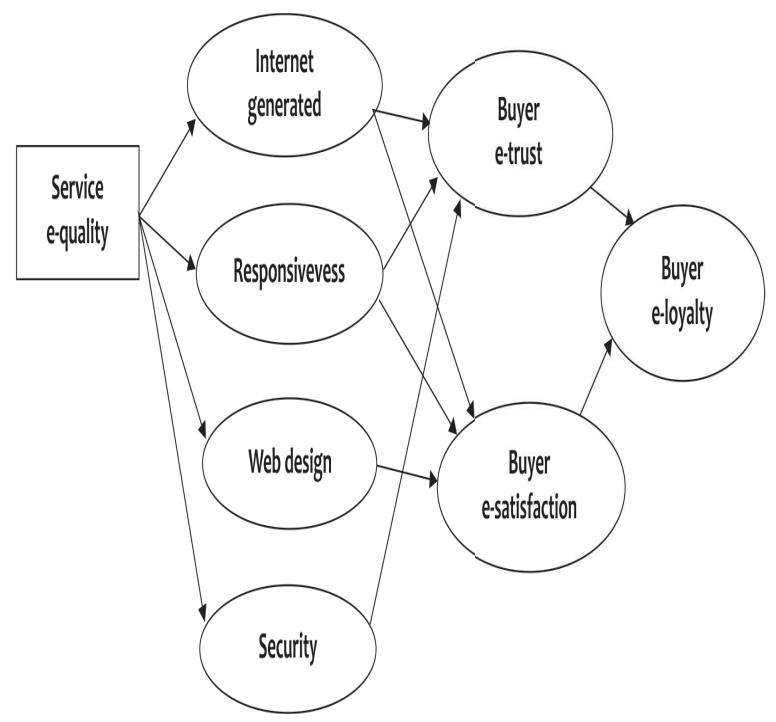

Figure 1 The influence of the dimensions of service e-quality on service user e-loyalty

Source: Kim, Jin \& Swinney, 2009, 240

The Internet conveniences offered to users by tourist agencies include: comfortability, a possibility of 24hour purchase 7 days in the week, time saving, the quickness and simplicity of searching offers, updated information and so on. Also, such favorable conditions disadvantages of the Internet purchase are reflected in the insecurity of performing financial transactions, a lack of trust and the elimination of personal contact between the agent and the client.

By identifying the dimensions of the quality of online services, their influence on the e-satisfaction of the users of tourism services is also analyzed. Figure 1 is the presentation of the influence of the determinants of the quality of online services on user e-loyalty. The key dimensions of the quality that have an influence on online buyers' trust and satisfaction are: accessibility, responsiveness, the website design and the degree of security in performing online transactions (Kim, Jin \& Swinney, 2009).

for payment exclude agencies' commissions and additional costs of purchase on the Internet. The

The dimensions of the online quality of services have an influence on the level of the service user e-trust and e-satisfaction. When developing online marketing relationships in tourism, first the segments of the online users of services who belong to the so-called " $Y$ " Buyers generation are initially identified (Nusair, Parsa \& Cobanoglu, 2011). Young users are mainly more motivated for online buying, but there has also been an ongoing increase in the number of those elderly ones, who, for the reason of their lacking free time, decide to buy via the Internet (Radosavljević, Maksimović \& Borisavljević, 2012). Buyers of online services, however, are less price sensitive in comparison with traditional buyers. On the other hand, they are more sensitive in view of providing comfortability when buying via the Internet. Accordingly, N. Ndubisi (2007) has proved that elderly buyers and women have a greater chance to become loyal in comparison with the others. Those with bigger salaries and making more valuable purchases are enabled special conveniences when purchasing and belong to the group of profitable buyers.

Similarly to traditional business operations, the interdependence between the service quality, the level of satisfaction and buyer loyalty is analyzed in online business operations in tourism. The perceived level of the service quality is the critical factor for the buyer's decision to stay loyal to an enterprise (stayers), whereas 
the price perception is only significant when they are making a decision to switch to another enterprise (switchers). The perceived service quality/price ratio can influence the level of user loyalty (Koi-Akrofi, Koi-Akrofi \& Welbeck, 2013). Apart from the service price, it is also significant to examine the influence of promotion, the type of the activity, the size of the enterprise, the business tradition and image, the buyer's decision to use the services provided by the same enterprises again.

\section{THE INFLUENCE OF THE WEBSITE ON TOURIST AGENCIES' MARKETING PERFORMANCES}

The process of creating a website in tourism encompasses the identification of the web elements, the visual context and the connecting of webpages. The three basic elements of the website are the construction, the content and the design (Siegel, 2004). The web content in tourist agencies includes detailed information about the tourism offer and the price, business contacts, the map of the agency's locations, hotels, restaurants and so on, which are compatible with the design of the website. Web design stands for the manner of organizing and presenting the web content.

Tourist agencies' web design represents the visual layout of the site which should contain an emotional dimension because it has an influence on the visitor's impression and experience and causes the buyer's positive or negative reactions. The building of the visitor's positive experience is also influenced by the content of the web with respect to the simplicity of search, the choice of a menu, updated and timely provided information and adaptation to visitors' individual requests and so forth (Chaffey, Mayer, Johnston \& Ellis-Chadwick, 2000). The same was also demonstrated by another study (Dedeke, 2016), which was conducted on the influence of the design and the content of a website on the decision the buyer makes on buying tourism services. In any case, the design and the content of tourist agencies' webs have a significant influence on the degree of the loyalty of the users of tourism services who search agencies' offers via the Internet. That is the subject matter of analysis in further in this paper.

On the basis of the presented model of the implementation of web marketing in tourist agencies (Figure 2), it can be concluded that management support, their proneness to risk and the introduction of innovative services are the key factors of an increase in the online sale of package arrangements in tourist agencies (Hussein, Ennew \& Kortam, 2012). The influence of the quality of the website on the satisfaction and loyalty of the users of tourism services also depends on their sociodemographic characteristics since mainly young and educated users, those who receive high monthly salaries, buy via the Internet the most.

The ways of using the website in tourist agencies are different. Primarily, the website serves to provide information, promote and conduct the placement of brochures, then to make orders and payments for and delivery of services via the Internet (e.g. by downloading) (Middleton et al, 2009, 263-264). However, it is also important to attract traditional users to visit agencies' websites in as big a number as possible. Virtual agencies (e.g. the "Expedia" online agency) invest in traditional promotional activities and via the electronic and printed media they create a positive image in the public and, to a great extent, attract traditional users of their services. In enterprises in tourism, operating mainly in a traditional way, the "marketing search" concept (search engine marketing) ...has ever-increasingly been applied. The process of users' search for information about tourism offers is conducted via the major Internet search engines, e.g. Google or Yahoo (Google recording over 82 million visits per month). The implementation of this concept of search engine marketing in doing business enables the improvement of the quality of the website and a better positioning of tourism enterprises while searching different online offers.

By giving recommendations or making comments on different Internet websites, tour operators help clients to make the right choice when travelling. The website visitors have a possibility of gaining an insight into the comments and experiences of those users who have previously travelled using the same 


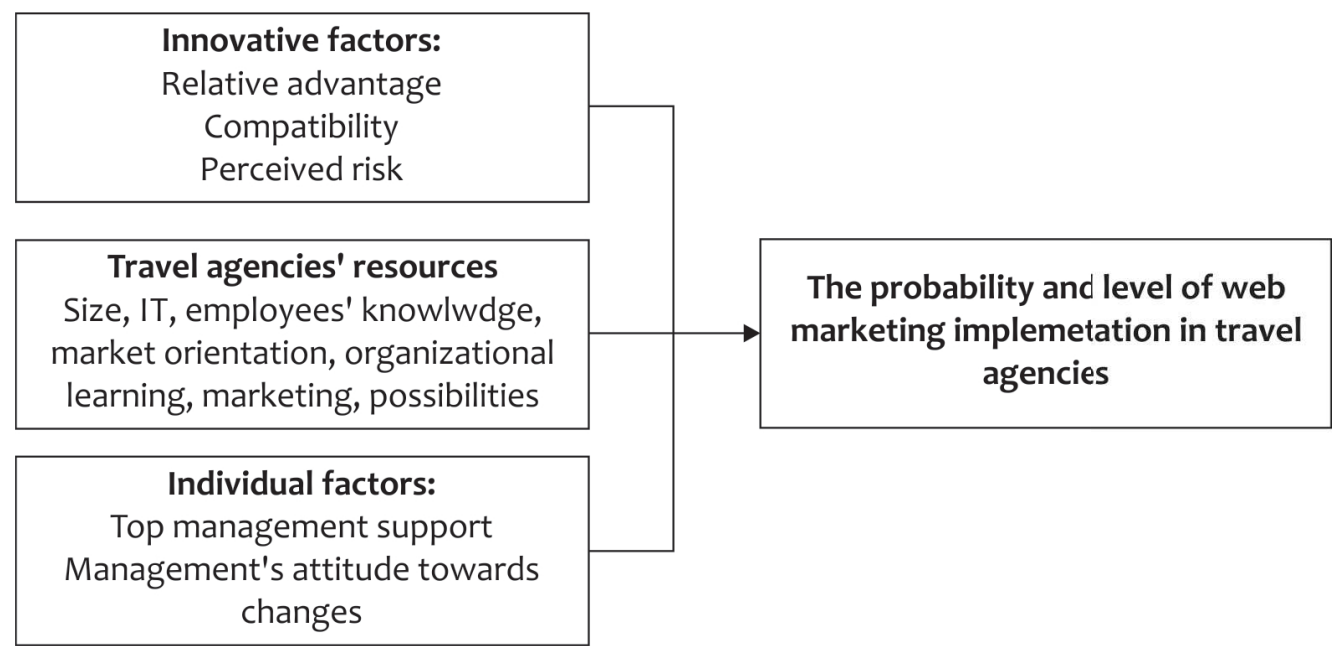

Figure 2 Web Marketing implementation in tourist agencies

Source: Hussein, Ennew \&Kortam, 2012, 5

agency. The results of the study (Phillips, Barners, Zigan \& Schegg, 2016) have shown that users' positive online recommendations have a significant influence on the improvement of tourism enterprises' business performances. Apart from the said, the number of independent websites that advertise traditional agencies and advise their clients for free, both prior to and during the travel (e.g. Tripadvisor), has also been increasing.

Specialized blogs provide free web spaces to enterprises with the aim to make a placement of their tourism offers and enable online visitors to share their unique experiences and impressions of their journeys. Blogs are a part of the online community, which consists of the groups of the visitors who have common interest and exchange their experiences via a forum or a chat (Álvarez et al, 2007). The sites of social networks, such as Facebook or Myspace, also enable visitors to create online communities. Blogs and social networks' sites have growing significance in making people knowledgeable of information and the promotion of tourism offers with the young population.

Tourist agencies' websites motivate clients to also personally come to the agency in case they may feel financially insecure when buying online. In RS, there have been an ever-increasing number of passengers who obtain information and make a buy via traditional agencies' websites, whereas there have been a smaller number of those who use online agencies' services. It can be concluded that, in the first phase of doing search and obtaining information, clients go on the Internet site and gain a certain level of trust in the agency. Should clients be making reservations for and buying arrangements exclusively via the Internet, the level of the current e-satisfaction will have no influence on an increase in the level of trust they have in traditional agencies. The reason for that is the fact that passengers make all their transactions via the website and there is no personal contact between the agency and the client.

The results of a study in the field of international tourism (Mamaghani, 2009) have shown that about 95\% of tourists obtain information via the Internet; then, about $93 \%$ of tourists visit websites with the aim to search tourism destinations, whereas approximately $45 \%$ of them contact tourist agencies by email, with the aim to obtain additional information and useful pieces of advice. This also confirms the starting assumption of the paper that agencies should be performing their business operations both via the Internet and in a traditional manner because there are those clients who 
will wish to make "a buy in a single place" (one stop shopping) and those who will independently create their arrangements, too. For example, via their websites, traditional agencies provide clients with useful pieces of information, brochures, catalogues and a possibility of making reservations and payments for and delivery of arrangements by downloading. On the other hand, online agencies (e.g. Expedia) invest in traditional promotion forms (e.g. by the electronic and printed media) so as to attract as big a number of the website visitors as possible, simultaneously contributing to the building of online agencies' better image (Middleton et $a l, 2009,260)$.

Starting from the said theoretical and practical aspects of tourist agencies' business operations, the subject matter of the research conducted in the paper is related to the role the Internet offer has in the development of relationships with clients. The aim of the research is to determine the extent to which the quality of a website has an influence on the buyer's decision to use the services of the same agency again and to recommend its services to others as well as on the business image. The research is based on a representative sample of tourism services users, who buy arrangements by going to the agency in person or via the website. The field research was conducted in the period from March to May 2015, within the territories of bigger cities/ towns in RS. The total number of the surveyed is 491 interviewees. The obtained data were processed and analyzed by applying statistical methods.

The research hypotheses we start from in this paper are as follows:

H1: A higher level of the quality of the Internet offer of an agency has a positive influence on the buyer's decision to use the services of the same agency again.

H2: A higher level of the quality of the Internet offer of an agency has a positive influence on the buyer's decision to recommend the agency's services to others.

H3: A higher level of the quality of the Internet offer of an agency has a positive influence on the business image of the agency.
By applying the binary logistic regression, the testing of the starting hypotheses was conducted, which is shown in the tables 2,3 and 4 .

During the testing of the factors of buyers' decision to recommend the services to others, the research results showed that the quality of the Internet offer has an influence on the buyer's decision to recommend the agency's services to other users as well, namely that the website design and content represent statistically significant variables in increasing the degree of user loyalty (Table 3). While examining the influence of the online offer on the competitiveness of enterprises in tourism, the influence of the quality of agencies' websites on the improvement of the agency's image on the market is also separately discussed. A research study in Egypt (Agag \& El-Masry, 2016), has also shown that users first of all buy the online services of those agencies which have an already established image on the market.

On the basis of the conducted binary logistic regression (Table 4), the research results showed that the quality design of the website has a significant influence on the improvement of the image of the agency, whereas the content of the website of an agency has no significant influence on the business image of the agency.

In connection with that, some authors (Chaffey et al, 2000) have also pointed at the connection between the online and the offline image of an enterprise. Namely, the implementation of Information Technology in an enterprise enables personalization and an individual treatment for service users, the availability of information accompanied by minimal costs of search for information, the simplicity of executing transactions via the Internet, comfortability, simplicity, as well as enjoyment, which leads to an increase Iin the level of online user satisfaction and loyalty, and indirectly to an increase in their trust in the traditional manner of buying. The research studies conducted in tourism so far have not been indicative of the positive influence of user online satisfaction on the level of trust they have in making a purchase of package arrangements in a traditional way (Álvarez et al, 2007). This is so for the reason of the fact that in traditional (offline) business operations the level of trust is built on the basis of personal relationships 
Table 2 The analysis of the influence of the quality of a website on the buyer's decision to use the services of the same agency again

\begin{tabular}{|c|c|c|c|c|c|c|c|}
\hline \multicolumn{8}{|c|}{ Classification Table } \\
\hline & & & & Ant & cipated $\mathrm{O}$ & tco & \\
\hline & & & \multicolumn{3}{|c|}{$\begin{array}{l}\text { Would you return and use your } \\
\text { tourist agency's services again? }\end{array}$} & \multirow{2}{*}{\multicolumn{2}{|c|}{$\begin{array}{c}\text { Percentage of accurate } \\
\text { anticipations }\end{array}$}} \\
\hline \multicolumn{3}{|c|}{ Observed Outcomes } & No & \multicolumn{2}{|r|}{ Yes } & & \\
\hline \multirow[t]{3}{*}{ Step 1} & $\begin{array}{l}\text { Would you return and use } \\
\text { your tourist agency's }\end{array}$ & & & 25 & 61 & & 29.1 \\
\hline & services again? & Yes & & 15 & 316 & & $95 \cdot 5$ \\
\hline & Total Percentage & & & & & & 81.8 \\
\hline \multicolumn{8}{|c|}{ Model Assessment } \\
\hline \multicolumn{3}{|c|}{$\begin{array}{l}\text { Coefficient } \\
\text { B }\end{array}$} & \multicolumn{4}{|c|}{$\begin{array}{l}\text { Statistical } \\
\text { significance } \\
\text { of the Test }\end{array}$} & $\operatorname{Exp}(B)$ \\
\hline \multirow[t]{3}{*}{ Step1 } & Website design & .941 & .165 & 32.458 & \multicolumn{2}{|c|}{.000} & 2.564 \\
\hline & Website content & .206 & .143 & 2.071 & \multicolumn{2}{|c|}{.150} & 1.229 \\
\hline & Constant & -2.474 & .484 & 26.082 & \multicolumn{2}{|c|}{.000} & .084 \\
\hline
\end{tabular}

Source: Author

Table 3 The analysis of the influence of the quality of agencies' websites on the buyer's decision to recommend the agency's services to others

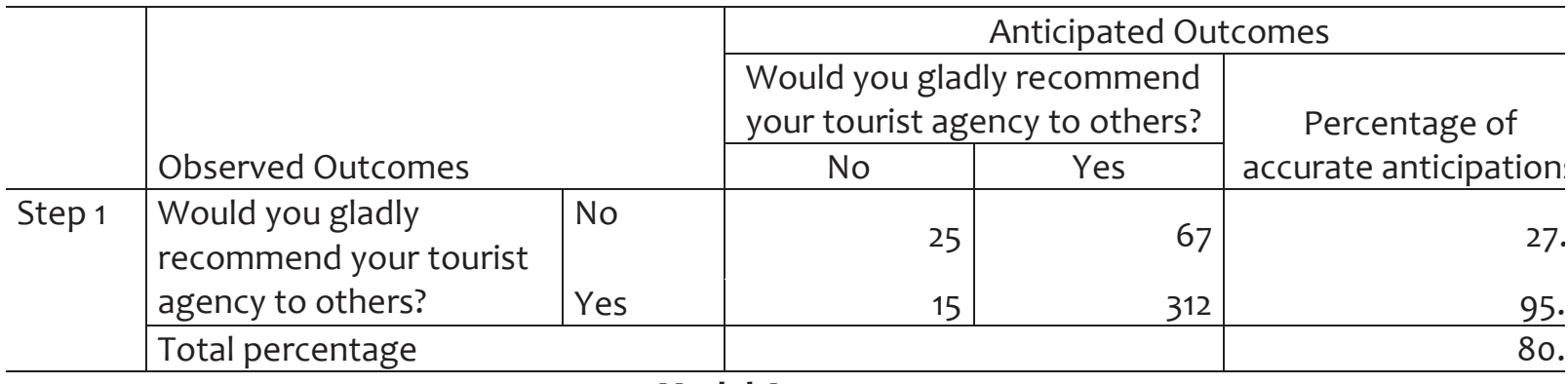

\begin{tabular}{ll|rrrrrr}
\hline & \multicolumn{3}{c}{ Model Assessment } \\
\hline & \multicolumn{3}{c}{$\begin{array}{c}\text { Standard } \\
\text { deviation }\end{array}$} & Wald & $\begin{array}{c}\text { Statistical } \\
\text { significance of the } \\
\end{array}$ & Test & Exp(B) \\
\hline Step 1 & Website design & .578 & .158 & 13.379 & .000 & 1.78 \\
& Website & .675 & .149 & 20.546 & .000 & 1.96 \\
& content & -2.936 & .506 & 33.664 & .000 & .05 \\
& Constant & & & & & &
\end{tabular}


the level of trust they have in making a purchase of package arrangements in a traditional way (Álvarez et

and contacts with the agency's employees. Clients who search, make reservations and buy offers via the Internet rarely decide to go to the agency in person, so that, simultaneously with an increase in the level of trust in online transactions, there is a decrease in the individual treatment for service users, the availability of information accompanied by minimal costs of search for information, the simplicity of executing transactions via the Internet, comfortability, simplicity, as well as enjoyment, which leads to an increase Iin the level of online user satisfaction and loyalty, and indirectly to an increase in their trust in the traditional manner of buying. The research studies conducted in tourism so far have not been indicative of the positive influence of user online satisfaction on traditional (offline) business operations the level of trust is built on the basis of personal relationships and contacts with the agency's employees. Clients who search, make reservations and buy offers via the Internet rarely decide to go to the agency in person, so that, simultaneously with an increase in the level of trust in online transactions, there is a decrease in the degree of clients' trust in agencies' business operations conducted in a traditional way. That is yet another reason why tourist agencies decided to do business both in the traditional way (through their business units) and via the Internet. A certain number of users wish to search via the Internet, but for the reason of their financial security, they make their purchase in a traditional way by going to the agency in person.

Table 4 The analysis of the influence of the level of the quality of agencies' websites on the business image of the agency

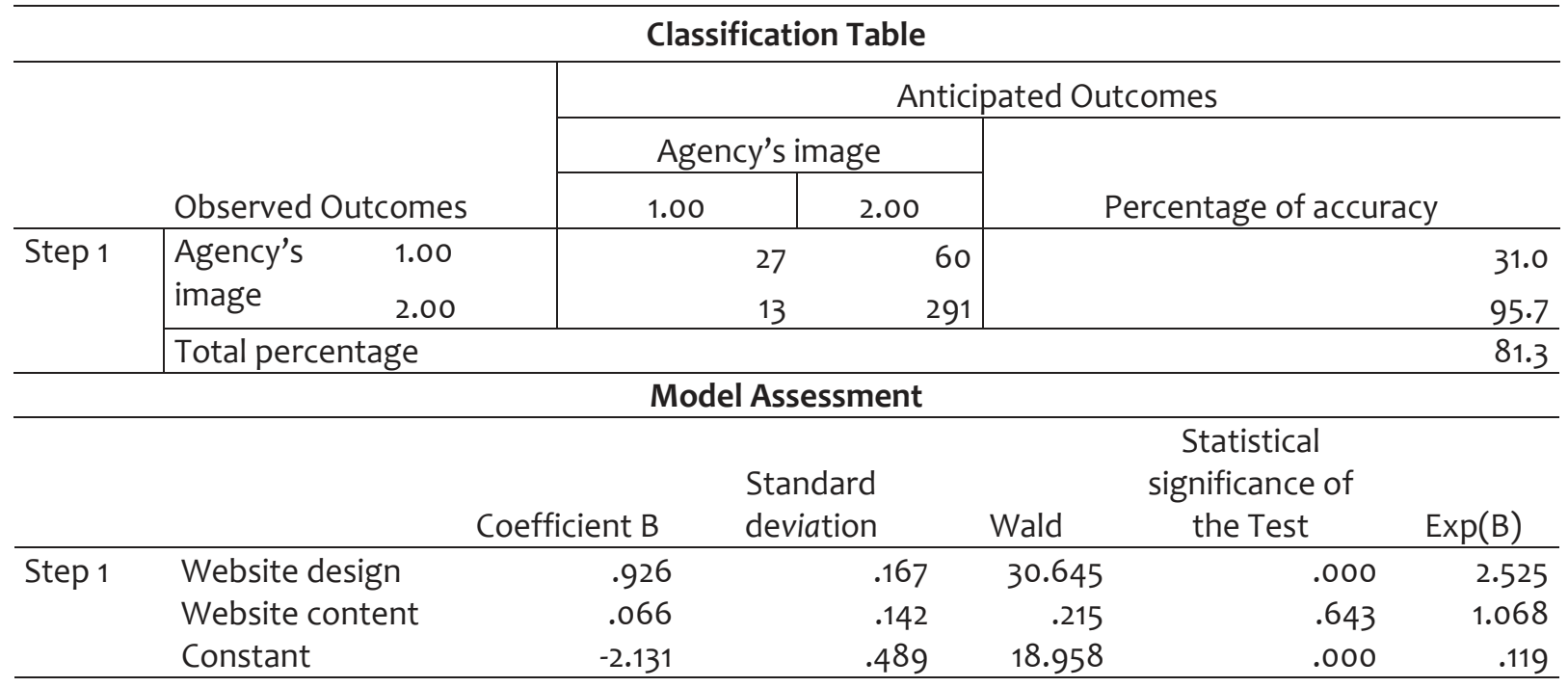

Source: Author

\section{CONCLUSION}

The implementation of the Internet in tourism business operations enables offering individual services to and a special treatment for users, but indirectly also has an influence on an increase in the purchasing arrangements in a traditional way. Tourist agencies step into online business operations and are competitors to virtual agencies by reducing the level of uncertainty during online purchasing, on the one hand, and increasing the level of client trust, on the other.

The research results presented in the paper have shown that tourist agencies' business success is based on the combined traditional and online approach. On the basis of the testing of the initial assumptions in the paper, it has been confirmed that tourist agencies' online offer represents a significant factor of increasing the degree of buyer loyalty and improving the image of 
agencies. At the same time, the design and the content of the websites of tourist agencies have to a significant extent an influence on buyers' decision to use the services of the same agency again, whereas the content of the website has no significant influence on buyers' decision to recommend the services of the agency to others. Differently from agencies' website design, a higher quality of the web content does not have an influence on the improvement of the agency's image. In the paper, however, the other dimensions of the online quality of the services that can significantly influence an increase in the degree of the loyalty of users of tourism services are not analyzed, which can be the subject matter of a future research study. In building quality relationships between enterprises and service users, the other factors, e.g. the level of user trust and loyalty, the process of resolving buyers' complaints in agencies etc. should be taken into consideration, too. Also, the subject matter of a separate examination can be the implementation of online business doing, too, in other tourism enterprises and the influence of the online offer on the improvement of total business performances.

The scientific contribution of this paper is reflected in the fact that the significant implementation of the combined traditional and online business doing in agencies in the improvement of their marketing performances has been proved. The practical contribution of the paper is related to a possibility of using the research results in the building of more quality relationships with buyers in agencies in the Republic of Serbia. It can be concluded that online business operations enable not only tourist agencies, but also the other participants in the tourism chain of the offer to achieve a competitive advantage and step onto the international tourism market.

\section{REFERENCES}

Agag, G., \& El-Masry, A. (2016). Why do consumer trust online travel websites? Drivers and outcomes of consumer trust toward online travel websites. Journal of Travel Research, 27, 1-23. doi: $10.1177 / 0047287516643185$

Álvarez, L., Martín, A., \& Casielles, R. (2007). Relationship marketing and information and communication technologies: Analysis of retail travel agencies. Journal of Travel Research, 45(4), 453-463. doi:10.1177/0047287507299593

Bilgihan, A., Okumus, F., Nusair, K., \& Kwun, D. (2011). Information technology applications and competitive advantageinhotelcompanies. Journal of Hospitalityand Tourism Technology, 2(2), 139-154. doi.org/10.1108/17579881111154245

Buhalis, D., \& Law, R. (2008). Progress in information technology and tourism management: 20 years on and 10 years after Internet-The state of e-Tourism research. Tourism Management, 29, 609-623. doi:10.1016/j.tourman.2008.01.005

Chaffey, D., Mayer, R., Johnston K., \& Ellis-Chadwick, F. (2000). Internet Marketing. London, UK: Prentice Hall.

Chen, C., \& Kao, Y. (2010) Relationships between process quality, outcome quality, satisfaction, and behavioural intentions for online travel agencies - Eevidence from Taiwan. The Service Industries Journal, 30(12), 2081-2092. doi: 10.1080/02642060903191108

Chiam, M., Soutar, G., \& Yeo, A. (2009). Offline and online travel packages preferences: A conjoint analysis. International Journal of Tourism Research, 11, 31-40. doi: 10.1002/jtr.679

Dedeke, A. (2016). Travel web-site design: Information task-fit, service quality and purchase intention. Tourism Management, 54, 541-554. doi: 10.1016/j.tourman.2016.01.001

Elliott, R., \& Boshoff, C. (2009). The marketing of tourism services using the internet: A resource-based view. South Africa of Journal Business Management, 40(3), 35-49.

Ho, C., \& Lee, Y. (2007). The development of an e-travel service quality scale. Tourism Management, 28(6), 1434-1449. doi:10.1016/j.tourman.2006.12.002

Hussein, R., Ennew, C., \& Kortam, W. (2012). The adoption of web-based marketing in the travel and tourism industry: An empirical investigation in Egypt. Journal of Innovation Management in Small \& Medium Enterprises, 1-23. doi: $10.5171 / 2012.143325$

Kim, J., Jin, B., \& Swinney, J. (2009). The role of retail quality, e-satisfaction and e-trust in online loyalty development process. Journal of Retailing and Consumer Services, 16(4), 239247. doi: 10.1016/j.jretconser.2008.11.019

Koi-Akrofi, G., Koi-Akrofi, J., \& Welbeck, J. (2013). Relationship marketing tactics and customer loyalty-a case of the mobile telecommunication industry in Ghana. Asian Journal of Business Management 5(1), 77-92.

Liu, Z., Park. S. (2015). What makes a useful online review? Implication for travel product websites. Tourism Management, 
47, 140-151. doi.org/10.1016/j.tourman.2014.09.020

Mamaghani, M. (2009). Impact of e-commerce on travel and tourism: An historical analysis. International Journal of Management, 26(3), 365-375.

Middleton, V., Fyall, A., Morgan, M., \& Ranchhod, A. (2009). Marketing in travel and tourism. Oxford, UK: Elsevier.

Mihajlović, I. (2012). The Impact of information and communication technology (ICT) as a key factor of tourism development on the role of Croatian travel agencies. International Journal of Business and Social Science, 3(24), 151-159.

Ndubisi, N. (2007). Relationship marketing and customer loyalty. Marketing Intelligence and Planning, 25(1), 98-106. doi. org/10.1108/02634500710722425

Ngai, E. W. T. (2005). Customer relationship management research (1992-2002), an academic literature review and classification. Marketing Intelligence \& Planning, 23(6), 582605. doi.org/10.1108/02634500510624147

Nusair, K. (2008). Business-to-customer relationship marketing for travel industry. Saarbrucken, Germany: Verlag Dr. Muller.

Nusair, K., Parsa, H., \& Cobanoglu, C. (2011). Building a model of commitment for Generation Y: An empirical study on e-travel retailers. Tourism Management, 32(4), 833-843. doi. org/10.1016/j.tourman.2010.07.008

Phillips, P., Barners, S., Zigan, K., Schegg, R. (2016). Understanding the impact of online reviews on hotel performance: An empirical analysis. Journal of Travel Research, 27, 1-15. doi: 10.1177/0047287516636481

Radosavljević, G. (2009). Menadžment u turizmu. Kragujevac, Rweb Srbija: Ekonomski fakultet Univrziteta u Kragujevcu.

Radosavljević, G., Maksimović, Lj., \& Borisavljević, K. (2012). Customer satisfaction with online offer of tourist agencies in Serbia. Actual Problems of Economics, 11(137), 436-448.

Siegel, C. (2004). Internet marketing: foundations and applications. Boston, USA: Houghton Miffin Company.

Thao, H., \& Swierczek, F. (2008). Internet use, customer relationships and loyalty in the Vietnamese travel industry. Asia Pacific Journal of Marketing and Logistics, 20(2), 190-210. doi.org/10.1108/13555850810864551

Unković, S., i Zečević, B. (2013). Ekonomika turizma. Beograd, Rweb Srbija: Ekonomski fakultet Univerziteta u Beogradu.

Yoo, W., Lee, Y., \& Park, J. (2010). The role of interactivity in e-tailing: Creating value and increasing satisfaction. Journal of Retailing and Consumer Services, 17(2), 89-96. doi:10.1016/j. jretconser.2009.10.003

Received on $9^{\text {th }}$ November 2016, after revision, accepted for publication on $26^{\text {th }}$ December 2016. Published online on $30^{\text {th }}$ December 2016.

Katarina Borisavljevic is a Teaching Assistant at the Faculty of Economics of University in Kragujevac, Kragujevac, the Republic of Serbia, where she teaches the subjects of: Management in Tourism and Hotel Management, and Economics and Organization of Trade Enterprises. She received her PhD degree at the Faculty of Economics, of the University of Belgrade, in the field of tourism. The key fields of her scientific-research interests are marketing and management in tourism and marketing channels management. 


\title{
UTICAJ INFORMACIONE TEHNOLOGIJE NA MARKETINŠKE PERFORMANSE TURISTIČKIH AGENCIJA
}

\author{
Katarina Borisavljević* \\ Univerzitet u Kragujevcu, Ekonomski fakultet
}

\begin{abstract}
Primena informacione tehnologije $\mathrm{u}$ turizmu donosi brojne prednosti svim učesnicima $\mathrm{u}$ lancu turističke ponude. Tradicionalne turističke agencije se putem interneta orijentišu i na online poslovanje. $S$ druge strane, internet utiče na smanjenje uloge posredovanja turističkih agencija. Predmet istraživanja u radu je primena interneta u poslovanju turističkih agencija u cilju unapređenja marketinških performansi. Cilj istraživanja je uticaj kvaliteta internet ponude turističkih agencija na razvoj odnosa sa kupcima i unapređenje imidža turističkih agencija koje posluju u Republici Srbiji. Rezultati istraživanja u radu su pokazali da viši nivo kvaliteta internet ponude agencija pozitivno utiče na lojalnost kupaca, kao i na imidž agencije. Poslovni uspeh turističkih agencija se bazira na kombinovanom pristupu tradicionalnog i online poslovanja.
\end{abstract}

Ključne reči: turistička agencija, internet, poslovni imidž, lojalnost kupaca

JEL Classification: M15, M31, Z30

\section{UVOD}

Efikasno upravljanje odnosima između subjekata u turističkom lancu ponude sprovodi se putem primene informacione tehnologije (IT). Pružaoci turističkih usluga (na primer, avio kompanije ili hoteli) putem interneta daju korisne informacije o ponudi i prodaji usluga posrednicima (turističkim agencijama) ili krajnjim korisnicima turističkih usluga. Tokom 60tih godina XX-og veka, uveden je kompjuterizovani rezervacioni sistem (Computer Reservation System - CRS) koji je bio u funkciji formiranja baza

\footnotetext{
* Korespondencija: K. Borisavljević, Univerzitet u Kragujevcu, Ekonomski fakultet, Đ. Pucara 3, 34000 Kragujevac, Republika Srbija; e-mail: katarinab@kg.ac.rs
}

podataka u avio sektoru (Radosavljević, 2009, 321). Avio kompanije su putem ovog sistema upravljale elektronskim rezervacijama i prosleđivale ih udaljenim ekspoziturama, turističkim posrednicima i putnicima. To je omogućilo i agencijama da jednostavnije obavljaju rezervacije, fleksibilnije posluju i sarađuju sa pružaocima usluga. Kasnije, uvođenjem globalnog distributivnog sistema (Global Distribution System - GDS) tokom 80-tih godina XX-og veka, dolazi do intenzivnijeg razvoja elektronskog turizma (e-turizma).

$\mathrm{U}$ relevantnoj literaturi navode se i prednosti i nedostaci primene IT u turizmu. Prema K. Nusair-u $(2008,9)$, ključne prednosti primene IT za preduzeća $\mathrm{u}$ turizmu su: globalno povezivanje, praćenje internih 
procesa i aktivnosti konkurenata, prilagođavanje usluga potrebama korisnika, povećanje lojalnosti online korisnika i dr. S druge strane, primena IT u turizmu omogućava korisnicima usluga: interaktivnost, fleksibilnost, jednostavnost obavljanja transakcija, veću mogućnost izbora turističkih ponuda, dostupnost informacija i sl. Međutim, R. Elliott i C. Boshoff (2005) ističu i ograničenja primene elektronskog turizma koja se odnose na: nizak nivo znanja i stručnosti kao i uslova za primenu tehnologije $u$ malim i srednjim preduzećima; ograničene mogućnosti za ulazak malih i srednjih preduzeća na elektronsko tržište; nedostatak efikasnog internet protoka, jer je potrebno da preduzeća dodatno plate za obavljanje bržeg internet pretraživanja kako bi se izbeglo zagušenje u online poslovanju i dr.

Predmet istraživanja $u$ radu je primena interneta $u$ poslovanju turističkih agencija u cilju unapređenja marketinških performansi. Cilj istraživanja je utvrđivanje stepena uticaja kvaliteta internet ponude turističkih agencija na razvoj odnosa sa kupcima i unapređenje imidža turističkih agencija koje posluju u Republici Srbiji (RS). Osnovna pretpostavka od koje se polazi u radu je uticaj internet ponude turističkih agencija na povećanje stepena lojalnosti korisnika usluga, tj. odluku korisnika da preporuče usluge agencije drugima i da ponovo koriste usluge iste agencije. Putem primene binarne logističke regresije izvršena je provera validnosti polaznih pretpostavki u radu.

U prvom delu rada ukazuje se na značaj primene interneta $u$ poslovanju turističkih preduzeća i na načine pružanja online usluga krajnim korisnicima. U drugom delu rada, razmatraju se karakteristike online usluga turističkih agencija, kao i odnos tradicionalnih agencija koje posluju putem interneta i virtuelnih agencija. Treći deo rada posvećen je istraživanju uticaja kvaliteta web sajta turističkih agencija na marketinške performanse.

\section{PRIMENA INTERNETA U PREDUZEĆIMA U TURIZMU}

Primena interneta, kao marketing instrumenta, $\mathrm{u}$ preduzećima $\mathrm{u}$ turizmu omogućava uštede u troškovima, brzinu obavljanja transakcija, dostupnost informacija, efikasnu komunikaciju, udobnost prilikom kupovine, primenu ciljnog marketinga, ulazak malih preduzeća na međunarodno turističko tržište i razvoj odnosa sa kupcima (Elliott \& Boshoff, 2009).

Primena interneta $\mathrm{u}$ turističkom poslovanju se bazira na resursnom pristupu. Uspešno upravljanje resursima (tehničkim, informacionim, ljudskim i sl.) doprinosi ostvarivanju komparativne prednosti preduzeća $\mathrm{u}$ turizmu. Primena interneta, GPS-a ili mobilnih telefona, utiče na kreiranje pozitivnog doživljaja i iskustva kod turista. Putnici koriste GPS u cilju jednostavnijeg i bržeg pronalaženja željene turističke destinacije. Avio prevoznici nude online rezervacije putnika putem mobilnih aplikacija i omogućavaju elektronsko čekiranje na aerodromima što povećava udobnost putovanja, smanjuje operativne troškove kao i broj zaposlenih, jer se prodaja obavlja isključivo putem elektronskih kioska (Yoo, Lee \& Park, 2010). Na primer, primena novih tehnoloških aplikacija u hotelima pruža bolju kontrolu troškova, efikasnije sprovođenje marketing strategija i tokova informacija, jednostavnost i udobnost online kupovine, dostupnost usluge 24h i 365 dana u toku godine i dr. Prema A. Bilgihan, F. Okumus, K. Nusair i D. Kwun (2011, 140), uspešnost primene tehnoloških aplikacija u preduzećima u turizmu će zavisiti od: usklađenosti poslovne strategije i primene IT rešenja, vrste IT aplikacija, mogućnosti primene IT, raspoloživih finansijskih sredstava i načina donošenja odluka u hotelima, kao i u drugim preduzećima iz oblasti turizma.

U budžet hotelima i ekonomskim tipovima hotela, IT se primenjuje u cilju povećanja operativne efikasnosti, dok u luksuznim hotelima uvođenje tehnoloških inovacija doprinosi unapređenju kvaliteta smeštajne ponude. Prema podacima Američke asocijacije putničkih agencija iz 2003, preko 64 miliona građana je koristilo internet u cilju pretraživanja destinacija, poređenja cena turističkih ponuda ili avio karata. Od ukupnog broja građana koji su koristili internet, skoro 42 miliona je rezervisalo putovanja putem interneta (Nusair, 2008, 21). Polazeći od značaja IT u turizmu, u radu se analizira kvalitet internet ponude i njen uticaj 
na povećanje lojalnosti klijenata prema turističkim agencijama koje posluju u RS.

Internet dovodi do transformacije pojedinih elemenata tradicionalnog koncepta marketing mix-a. $\mathrm{U}$ tom kontekstu, $\mathrm{tz}$. dinamični paket $\mathrm{u}$ turizmu (Middletion, Fayll \& Morgan, 2009, 268) predstavlja zamenu za turistički proizvod, jer pruža fleksibilniji i brži sistem rezervisanja za putnike, omogućava masovnu kastomizaciju i prilagođavanje potrebama pojedinačnih korisnika. Turističke agencije koje sarađuju sa tzv. bankama koje pružaju usluge smeštaja (bad banks) nude niže cene hotelskih usluga u odnosu na druge agencije. Pored online transparentnosti cena ponuda, putnici imaju i mogućnost izbora datuma putovanja, tipa prevoza, vrste smeštaja putem interneta i sl. Online distribucija obuhvata online rezervaciju i dodatne sadržaje destinacijske ponude, poput društvenih atrakcija ili fakultativnih izleta, a da pri tome nema čekanja klijenata $u$ redovima $u$ poslovnicama agencija. Prodaja aranžmana putem online kanala distribucije omogućava izlazak turističkih preduzeća na inostrano tržište. Online promocija se obavlja putem web sajta, a posebno je značajna uloga kvaliteta web sajta u povećanju nivoa lojalnosti online korisnika, a što je predmet istraživanja u radu.

Internet poslovanje se može obaviti putem rezervacionih sistema, virtuelnih ili online agencija (Expedia), pretraživača (Google, Kayak), društvenih mreža, web portala (Tripadvisor), sajtova za poređenje cena različitih paket aranžmana (Kelkoo) i sajtova turističkih ponuđača ili posrednika (Buhalis \& Law, 2009). K. Nusair (2008) je prikazao različite načine pružanja online usluga krajnim korisnicima (Tabela 1).

Tabela 1 Načini online poslovanja

\begin{tabular}{l|l|l}
\hline Maloprodavci & \multicolumn{1}{|c}{ Opis posla } & Primer \\
\hline Online agencije & $\begin{array}{l}\text { Prodaja različitih vrsta turističkih proizvoda od stane više } \\
\text { ponuđača. Turistički proizvodi uključuju usluge avio prevoza, } \\
\text { hotela, rent-a-car-a, kruzera i sl. }\end{array}$ & $\begin{array}{l}\text { www.travelocity.com } \\
\text { www.expedia.com } \\
\text { www.orbitz.com }\end{array}$ \\
$\begin{array}{l}\text { Web sajtovi } \\
\text { ponuđača usluga }\end{array}$ & $\begin{array}{l}\text { Prodaja sopstvenih paket aranžmana putem interneta ili poslovnih } \\
\text { partnera }\end{array}$ & $\begin{array}{l}\text { www.Starwood.com } \\
\text { www.AA.com }\end{array}$ \\
Aukcije & $\begin{array}{l}\text { Portali koji nude mogućnosti bukiranja u okviru turističke sekcije. } \\
\text { agencijama. Yahoo koristi Travelocity- rezervacione kapacitete }\end{array}$ & www.yahoo.com \\
Pretraživači & $\begin{array}{l}\text { Kupci pretražuju proizvode putem ključne reči, a putem hiper } \\
\text { linkova turističkih ponuđača može se izabrati određena ponuda }\end{array}$ & $\begin{array}{l}\text { www.gooogle.com } \\
\text { www.travelzoo.com } \\
\text { www.overture.com }\end{array}$ \\
Šoping ponuđači & $\begin{array}{l}\text { Oni nude web sajtove ponuđača i prezentuju ukupne rezultate } \\
\text { pretraživanja } \\
\text { Kupci postavljaju određene zahteve o željenim atributima } \\
\text { proizvoda, ceni i drugim uslovima, a web sajt pretražuje ponuđače } \\
\text { koji će ispuniti tražene ili unapred postavljenje uslove }\end{array}$ & $\begin{array}{l}\text { www.kayak.com } \\
\text { www.sidestep.com }\end{array}$ \\
$\begin{array}{l}\text { Web sajtovi } \\
\text { obrnute aukcije }\end{array}$ & www.priceline.com \\
\hline
\end{tabular}

Izvor: Autor, prema K. Nusair, 2008, 22

Na osnovu Tabele 1, može se zaključiti da postoje preduzeća koja nude različite načine online prodaje turističkih aranžmana. Online agencije prodaju usluge smeštaja, prevoza, rent-a car i dr, od strane više ponuđača. Turistička preduzeća mogu da prodaju sopstvene aranžmane putem web sajtova ili hiperlinkova, na osnovu kojih korisnici pretražuju turističke ponude. 
Postoji razlika u cenama u prodaji paket aranžmana ili avio karata tradicionalnih i virtuelnih agencija. Naime, one su niže u okviru turističke ponude virtuelnih agencija (Ngai, 2005). Što se tiče avio karata, putnici tragaju za povoljnijim cenama karata putem interneta, što povećava udobnost kupovine i stepen konkurentnosti u online okruženju. Globalne virtuelne agencije (na primer, Expedia, Orbitz, Lastminute.com, Opodo, Travelocity itd.) pružaju klijentima mogućnost kupovine na jednom mestu (one-stop shopping) putem interaktivnog web sajta, što je prednost $\mathrm{u}$ odnosu na tradicionalne turističke agencije. Traganje za informacijama i davanje preporuka putem interneta, kao i online proces upravljanja žalbama, mogu pozitivno da utiču i na imidž agencije. Takođe, u cilju minimiziranja nesigurnosti prilikom online kupovine, korisnici se sve više oslanjaju na preporuke drugih online korisnika (Thao \& Swierczek, 2008). Prema rezultatima jednog istraživanja (Liu \& Park, 2015), 83\% međunarodnih turista koristi internet $\mathrm{u}$ fazi planiranja putovanja, pri čemu se njih $43 \%$ oslanja na online komentare i preporuke drugih turista.

\section{INTERNET PONUDA TURISTIČKIH AGENCIJA}

Primena informacione tehnologije $\mathrm{u}$ turizmu dovodi do smanjenje troškova poslovanja i eliminisanja uloge posrednika u kanalima maketinga (Álvarez, Martín \& Casielles, 2007). Mnogi pružaoci turističkih usluga registruju sopstvene online agencije. Turoperatori mogu da plasiraju ponude putem svojih online portala. Samostalne virtuelne agencije (na primer, Lastminute.com, Booking.com, Expedia i dr.) postaju najveći konkurenti tradicionalnim agencijama. Takođe, na tradicionalno poslovanje agencija utiču i low cost kompanije, jer uglavnom pružaju povoljnije usluge posredovanja od agencija (na primer informativnosavetodavne i promotivno-prodajne aktivnosti), kao što su: usluge rentiranja automobila, hotelski smeštaj, usluge osiguranja i sl. (Mamaghani, 2009).

Međutim, primena interneta $\mathrm{u}$ turizmu pruža mogućnost da se turističke agencije orijentišu i na online prodaju. U tom kontekstu, one pružaju individualne usluge i specijalne tretmane, što će posredno dovesti i do povećanja tradicionalne kupovine tj. porasta broja ličnih odlazaka klijenata $\mathrm{u}$ agenciju (Álvarez, Martín \& Casielles, 2007). S druge strane, internet utiče na smanjenje uloge posredovanja koju imaju agencije. Međutim, agencije će i dalje zadržati dominantnu ulogu na inostranom i domaćem turističkom tržištu, jer će se kupci i dalje oslanjati na njihove profesionalne usluge informisanja, planiranja putovanja i bukiranja (Unković i Zečević, 2013, 95). To je zbog toga što će doći do smanjenja neizvesnosti online prodaje i povećanja nivoa poverenja korisnika $\mathrm{u}$ određenu turističku agenciju.

Karakteristike online usluga su visok stepen diferenciranosti i neopipljivosti ponude, ali i nizak stepen učešća klijenata u kreiranju paket aranžmana (Chiam, Soutar \& Yeo, 2009). Istraživanje je pokazalo da se oko $95 \%$ turista u svetu informiše putem interneta, oko 93\% turista posećuje web sajtove u cilju pretraživanja turističkih destinacija, a oko $45 \%$ kontaktira turističke agencije putem e-mail-a u cilju dobijanja dodatnih informacija i korisnih saveta (Mamaghani, 2009, 365). To je još jedan dokaz da agencije treba da posluju putem interneta, ali i u okviru tradicionalnih poslovnica. Kako M. Mamaghani (2009) navodi, postoje različiti profili klijenata prilikom odabira turističkog aranžmana. Jedna grupa klijenata će želeti da obavi kupovinu ukupne turističke ponude ili „kupovinu na jednom mestu“, a druga da samostalno kreira aranžman $u$ skladu sa svojim preferencijama.

Turističke agencije sve više razvijaju online odnose sa pružaocima usluga (na primer, hotelima, avio kompanijama i sl.) i korisnicima usluga. Prema podacima Centra za tržišno informisanje (Agag \& el-Masry, 2016), prodaja turističkih putovanja ostvaruje najveće učešće $(48,9 \%)$ u ukupnoj prodaji online proizvoda i usluga. U periodu 2011-2014, došlo je do povećanja prodaje online turističkih ponuda za $10 \%$ na međunarodnom tržištu, a do kraja 2016. godine godišnja stopa rasta online turističkih aranžmana će iznositi $8 \%$.

U cilju analize nivoa primene elektronskog poslovanja $u$ turističkim agencijama $u$ RS, sprovedeno je istraživanje na teritoriji većih gradova (Radosavljević, Maksimović \& Borisavljević, 2012). 
$\mathrm{Na}$ osnovu strukturiranog upitnika, obavljen je lični intervju sa menadžerima u 62 turističke agencije koje posluju u RS. Na osnovu analize prikupljenih podataka pokazano je da je oko $15 \%$ turističkih agencija nudilo paket aranžmane isključivo putem interneta, dok su ostale agencije sprovodile tradicionalan i elektronski način prodaje paket aranžmana. Takođe, istraživanje je pokazalo da agencije najviše koriste mejl i telefon, u cilju izgradnje i održavanja odnosa sa poslovnim partnerima i klijentima. Pored toga, one koriste fax, kataloge ili web sajtove. Rezultati istraživanja su pokazali da veliki broj faktora utiče na primenu interneta $u$ poslovanju turističkih agencija. Zahtevi zaposlenih $\mathrm{u}$ agencijama i klijenata utiču, u najvećoj meri, na primenu interneta $u$ poslovanju agencija (preko 50\%), a zatim slede zahtevi poslovnih partnera i uticaj konkurenata (oko 20\%). Na osnovu navedenih rezultata istraživanja može se zaključiti da turističke agencije u RS primenjuju tradicionalne i elektronske načine komuniciranja sa partnerima (hotelima, avio kompanijama i sl.) i klijentima. Slično navedenim rezultatima, i drugi autori (na primer, Mihajlović, 2012) zaključuju da primena interneta u poslovanju turističkih agencija ne može da zameni tradicionalne aktivnosti koje se baziraju na uspostavljanju ličnog kontakta sa klijentima, kao preduslova povećanja njihove lojalnosti. Takođe, internet pruža mogućnost korisnicima da jednostavno pređu kod drugog ponuđača ili porede cene konkurentskih ponuda, što utiče negativno na održavanje dugoročnih odnosa između online korisnika i turističkih agencija.

U ekonomski manje razvijenim zemljama, preferiran način kupovine turističkog aranžmana je odlazak klijenta u lokalnu turističku agenciju i uspostavljanje ličnog kontakta sa osobljem agencije. Zbog toga tradicionalni način prodaje $\mathrm{u}$ kombinaciji sa online prodajom turističkih agencija najviše utiče na razvoj odnosa sa klijentima.

$\mathrm{U}$ analizi uticaja primene interneta $\mathrm{u}$ turističkim agencijama na povećanje satisfakcije i lojalnosti online korisnika, polazi se od sledećih dimenzija kvaliteta online usluga: informisanosti, sigurnosti i funkcionalnosti web sajta, zatim od odnosa sa korisnicima, pružanja individualnih usluga, interaktivne komunikacije, kao i od stope davanja odgovora na pojedinačne zahteve korisnika. Nivo kvaliteta turističke ponude agencija značajno utiče na stepen e-satisfakcije i e-lojalnosti korisnika (Ho \& Lee, 2007).

$\mathrm{U}$ analizi razvoja online odnosa sa kupcima u agencijama, M. Chen i Z. Kao (2010) su identifikovali dve ključne dimenzije kvaliteta online usluga: kvalitet procesa i kvalitet usluga. Kvalitet procesa se analizira na osnovu jednostavnosti korišćenja, preglednosti i funkcionalnosti sajta, na osnovu pružanja tačnih ili preciznih informacija, kao i na osnovu dizajna web sajta, što pozitivno utiče na satisfakciju i lojalnost online klijenata. Merenje kvaliteta procesa se vrši na osnovu analize interakcije posetilaca i web sajta, što će se pozitivno odraziti na percipirani nivo ukupnog kvaliteta online usluga i online satisfakcije korisnika.

U internet pogodnosti, koje turističke agencije nude korisnicima, spadaju: udobnost, mogućnost kupovine $24 \mathrm{~h}$ i sedam dana u nedelji, ušteda vremena, brzina i jednostavnost pretraživanja ponuda, ažuriranost informacija i sl. Takođe, povoljni uslovi plaćanja isključuju proviziju agencija i dodatne troškove internet kupovine. Nedostaci internet kupovine se ogledaju $u$ nesigurnosti obavljanja finansijskih transakcija, nedostatku poverenja i eliminisanju ličnog kontakta između agenata i klijenata.

Putem identifikovanja dimenzija kvaliteta online usluga, analizira se i njihov uticaj na e-lojalnost korisnika turističkih usluga. Na Slici 1 je prikazan uticaj determinanti kvaliteta online usluga na e-lojalnost korisnika. Ključne dimenzije kvaliteta koje utiču na poverenje i satisfakciju online kupaca su: pristupačnost, responzivnost, dizajn web sajta i stepen sigurnosti obavljanja online transakcija (Kim, Jin \& Swinney, 2009). 


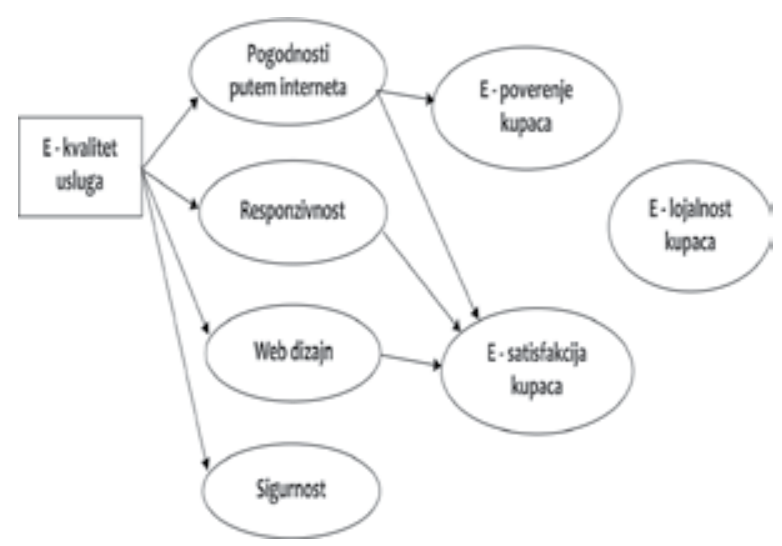

Slika 1 Uticaj dimenzija e-kvaliteta usluga na e-lojalnost korisnika usluga

Izvor: Kim, Jin \& Swinney, 2009, 240

Dimenzije online kvaliteta usluga utiču na nivo e-poverenja i e-satisfakcije korisnika usluga. Prilikom spovođenja online marketing odnosa u turizmu polazi se od identifikovanja segmenata online korisnika usluga koji pripadaju tzv. generaciji Y kupaca (Nusair, Parsa \& Cobanoglu, 2011). Mladi korisnici uglavnom su više motivisani za online kupovinu, ali povećava se i broj onih starijih, koji se sve više zbog nedostatka slobodnog vremena odlučuju za kupovinu putem interneta (Radosavljević, Maksimović \& Borisavljević, 2012). Međutim, kupci online usluga su manje cenovno osetljivi u odnosu na tradicionalne kupce. Ali, oni su više osetljivi u pogledu pružanja udobnosti prilikom internet kupovine. U skladu sa tim, N. Ndubisi (2007) je dokazao da stariji kupci i žene imaju veću šansu da postanu lojalni u odnosu na ostale. Oni koji imaju veća primanja i obavljaju vrednije kupovine, dobijaju specijalne pogodnosti prilikom kupovine i spadaju u grupu profitabilnih kupaca.

Slično kao i kod tradicionalnog poslovanja, u online turističkom poslovanju ispituje se međuzavisnost kvaliteta usluga, nivoa satisfakcije i lojalnosti kupaca. Percipirani nivo kvaliteta usluga je presudan faktor kod odluke kupaca da ostanu lojalni preduzeću, dok je cenovna percepcija značajna kada oni odlučuju da napuste preduzeće. Percipiran odnos kvaliteta i cene usluga može da utiče na nivo lojalnosti korisnika (Koi-Akrofi, Koi-Akrofi \& Welbeck, 2013). Pored cene usluga, značajno je ispitati i uticaj promocije, vrste delatnosti, veličine preduzeća, poslovne tradicije i imidža, na odluku kupaca da ponovo koriste usluge istog preduzeća.

\section{UTICAJ WEB SAJTA NA MARKETINŠKE PERFORMANSE TURISTIČKIH AGENCIJA}

Proces kreiranja web sajta $\mathrm{u}$ turizmu, obuhvata identifikovanje elemenata web-a, vizuelnog konteksta i povezivanje web stranica. Tri osnovna elementa web sajta su konstrukcija, sadržaj i dizajn (Siegel, 2004). Web sadržaj u turističkim agencijama obuhvata detaljne informacije o turističkoj ponudi i ceni, poslovnim kontaktima, mapi lokacija agencija, hotela, restorana i dr, koje su kompatibilne sa dizajnom web sajta. Web dizajn predstavlja način organizovanja i prezentovanja web sadržaja.

Web dizajn turističkih agencija predstavlja vizuelni izgled sajta koji treba da sadrži emotivnu dimenziju, jer utiče na doživljaj i iskustvo posetilaca i izaziva pozitivne ili negativne reakcije kod njih. Na izgradnju pozitivnog iskustva posetilaca utiče i sadržaj web-a, u pogledu jednostavnosti pretraživanja, izbora menija, ažuriranosti i pravovremenosti pružanja informacija, prilagođenosti pojedinačnim zahtevima posetilaca i dr. (Chaffey, Mayer, Johnston \& Ellis-Chadwick, 2000). To je pokazala studija (Dedeke, 2016) koja se bavila uticajem dizajna i sadržaja web sajta na odluku korisnika o kupovini turističkih usluga. U svakom slučaju, dizajn i sadržaj web-a turističkih agencija značajno utiču na stepen lojalnosti korisnika turističkih usluga koji pretražuju ponude agencija putem interneta.

$\mathrm{Na}$ osnovu prikazanog modela primene web marketinga $\mathrm{u}$ turističkim agencijama (Slika 2), može se zaključiti da su podrška menadžmenta, njihova sklonost ka riziku i uvođenje inovativnih usluga ključni faktori povećanja online prodaje paket aranžmana $\mathrm{u}$ turističkim agencijama (Hussein, Ennew \& Kortam, 2012). Uticaj kvaliteta web sajta na satisfakciju i lojalnost korisnika turističkih usluga zavisi i od njihovih sociodemografskih karakteristika, jer uglavnom mladi i obrazovani 


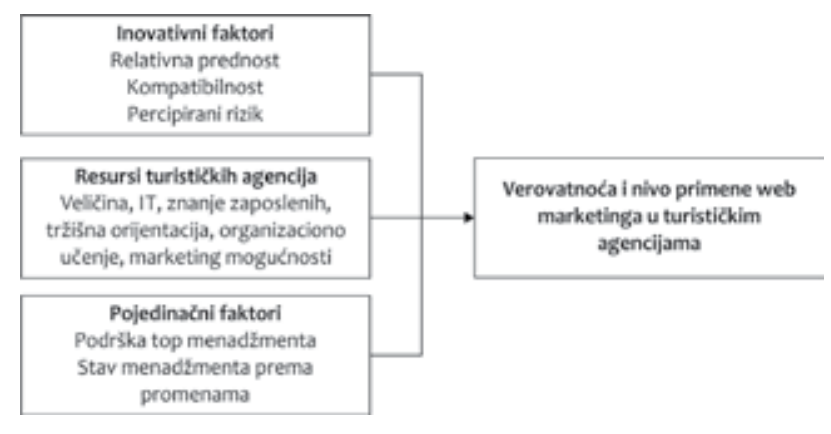

Slika 2 Uticaj dimenzija e-kvaliteta usluga na e-lojalnost korisnika usluga

Izvor: Hussein, Ennew \& Kortam, 2012, 5

korisnici, koji imaju visoka mesečna primanja, najviše kupuju putem interneta

Različiti su načini korišćenja web sajta u turističkim agencijama. Primarna upotreba sajta je pružanje informacija, obavljanje promocije i plasmana brošura, zatim naručivanje, plaćanje i isporuka usluga putem interneta (na primer, putem downloading-a) (Middleton at al, 2009, 263-264). Međutim, važno je privući i tradicionalne korisnike da u što većem broju posete web sajt agencija. Virtuelne agencije (Expedia) ulažu u tradicionalne promotivne aktivnosti i putem elektronskih i štampanih medija kreiraju pozitivan imidž $u$ javnosti i privlače $u$ velikoj meri tradicionalne korisnike usluga. U preduzećima u turizmu, koja posluju uglavnom na tradicionalan način, sve se više primenjuje koncept „marketing pretraživanja”. Proces traganja korisnika za informacijama o turističkim ponudama se odvija putem najvećih internet pretraživača, na primer, Google ili Yahoo-a (Google beleži preko 82 miliona poseta na mesečnom nivou). Primena ovog koncepta marketing pretraživanja $\mathrm{u}$ poslovanju omogućava poboljšanje kvaliteta web sajta i bolje pozicioniranje turističkih preduzeća prilikom pretraživanja različitih online ponuda.

Turoperatori, putem davanja preporuka ili ostavljanja komentara na različitim internet sajtovima, pomažu klijentima da naprave pravi izbor prilikom putovanja. Posetioci sajta imaju mogućnost da pogledaju komentare i iskustva onih korisnika koji su prethodno putovali putem iste agencije. Rezultati studije (Phillips, Barners, Zigan \& Schegg, 2016) su pokazali da pozitivne online preporuke korisnika značajno utiču na poboljšanje poslovnih performansi turističkih preduzeća. Pored toga, povećava se i broj nezavisnih web sajtova koji besplatno reklamiraju tradicionalne agencije i pružaju savete klijentima, pre i u toku putovanja (na primer, Tripadvisor).

Specijalizovani blogovi pružaju besplatne web prostore preduzećima u cilju plasmana turističkih ponuda i omogućavaju online posetiocima da prenesu svoja jedinstvena iskustva i doživljaje sa svojih putovanja. Blogovi su deo online zajednice, koju čine grupe posetilaca koje imaju zajednička interesovanja i razmenjuju iskustva putem foruma ili četa (Álvarez et al, 2007). Takođe, i sajtovi društvenih mreža, poput Faceebook-a ili Myspace-a, omogućavaju posetiocima da kreiraju online zajednice. Blogovi i sajtovi društvenih mreža imaju rastući značaj u informisanju i promovisanju turističkih ponuda kod mlade populacije.

Web sajtovi turističkih agencija motivišu klijente i da lično posete agenciju, ukoliko imaju finansijsku nesigurnost prilikom online kupovine. U RS je sve veći broj putnika koji se informišu i obavljaju kupovinu putem web sajta tradicionalnih agencija, a manji broj je onih koji koriste usluge online agencija. Može se zaključiti da u prvoj fazi pretraživanja i informisanja, klijenti posećuju internet sajt i stiču određeni nivo poverenja $u$ agenciju. Ukoliko klijenti obavljaju rezervaciju i kupovinu aranžmana isključivo putem interneta, nivo trenutnog e-zadovoljstva neće uticati na povećanje nivoa poverenja koje oni imaju u tradicionalne agencije. Razlog tome je što putnici sve transakcije obavljaju putem web sajta i ne dolazi do ličnog kontakta između agencije i klijenata.

Rezultati studije iz oblasti međunarodnog turizma (Mamaghani, 2009) su pokazali da se oko 95\% turista informiše putem interneta, oko $93 \%$ turista posećuje web sajtove u cilju pretaživanja turističkih destinacija, dok oko $45 \%$ njih kontaktira turističke agencije putem mejla, u cilju dobijanja dodatnih informacija i korisnih saveta. To potvrđuje i polaznu pretpostavku rada da agencije treba da posluju i putem interneta i na tradicionalan način, jer postoje oni klijenti koji će želeti da obave "kupovinu na jednom mestu“, ali i klijenti koji će samostalno kreirati aranžmane. 
Na primer, tradicionalne agencije, putem web sajta, pružaju korisne informacije, brošure, kataloge i mogućnost rezervacija, plaćanja i isporuke aranžmana putem downloading-a. S druge strane, online agencije (na primer, Expedia) ulažu u tradicionalne vidove promocije (na primer, putem elektronskih i štampanih medija) kako bi privukle što veći broj posetilaca web sajtu i time doprineli izgradnji boljeg imidža online agencija (Middleton et al, 2009, 260).

Polazeći od navedenih teorijskih i praktičnih aspekata poslovanja turističkih agencija, predmet istraživanja $\mathrm{u}$ radu se odnosi na ulogu internet ponude $\mathrm{u}$ razvoju odnosa sa kupcima. Cilj istraživanja je utvrđivanje $u$ kojoj meri kvalitet web sajta agencija utiče na odluku kupaca da ponovo koriste usluge iste agencije i preporuče usluge drugima, kao i na poslovni imidž. Istraživanje je bazirano na reprezentativnom uzorku korisnika turističkih usluga, koji kupuju aranžmane ličnim odlaskom $\mathrm{u}$ agenciju ili putem web sajta. Terensko istraživanje je realizovano $\mathrm{u}$ periodu martmaj 2015, na području većih gradova u RS. Ukupno je anketiran 491 ispitanik. Korišćenjem statističkih metoda izvršena je obrada i analiza prikupljenih podataka.

Hipoteze istraživanja su:

H1: Viši nivo kvaliteta internet ponude agencije pozitivno utiče na odluku kupaca da ponovo koriste usluge iste agencije.

H2: Viši nivo kvaliteta internet ponude agencije pozitivno utiče na odluku kupaca da preporuče usluge agencije dugima.

H3: Viši nivo kvaliteta internet ponude agencije pozitivno utiče na poslovni imidž.

Putem logističke binarne regresije, izvršeno je testiranje polaznih hipoteza (tabele 2, 3 i 4).

Tabela 2 Analiza uticaja kvaliteta web sajta na odluku kupaca da ponovo koriste usluge iste agencije

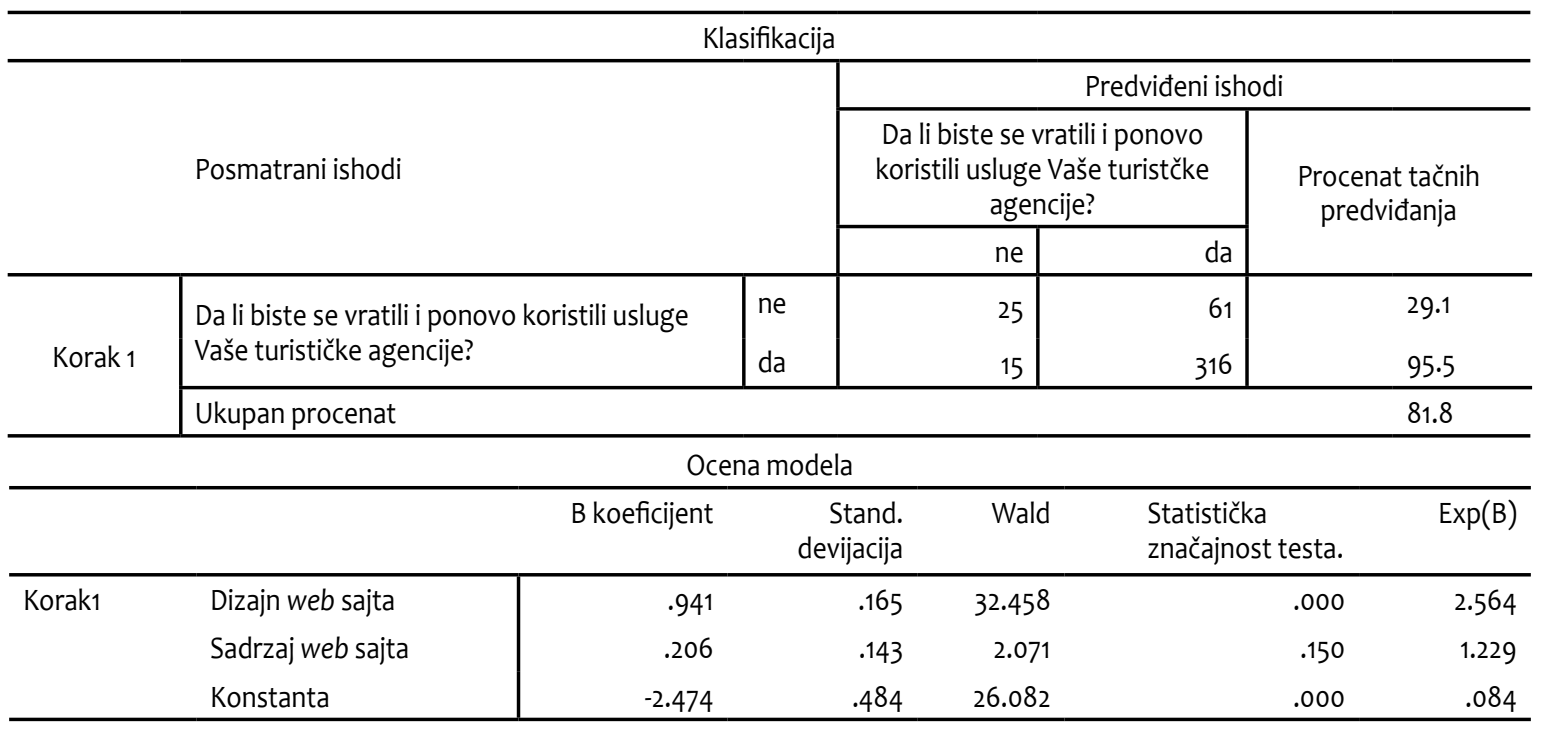

Izvor: Autor

Na osnovu rezultata prikazanih u Tabeli 2, može se zaključiti da dizajn web sajta u značajnoj meri utiče na odluku kupaca da ponovo koriste usluge iste agencije, dok sadržaj web sajta turističkih agencija nije značajan u izgradnji dugoročnih odnosa sa kupcima.

Prilikom ispitivanja faktora odluke kupaca da preporuče usluge drugima, rezultati istraživanja su pokazali da kvalitet internet ponude utiče na odluku kupaca da preporuče usluge agencije i drugim korisnicima, tj. dizajn i sadržaj web sajta predstavljaju statistički značajne varijable $u$ povećanju stepena lojalnosti korisnika (Tabela 3). Prilikom ispitivanja uticaja online ponude na konkurentnost preduzeća $\mathrm{u}$ turizmu, $\mathrm{u}$ radu se posebno razmatra i uticaj 
kvaliteta web sajta agencija na unapređenje imidža agencije na tržištu. Istraživanje u Egiptu (Agag \& ElMasry, 2016), takođe, pokazalo je da korisnici kupuju online usluge, pre svega, onih agencija koje imaju izgrađen imidž na tržištu.
$\mathrm{Na}$ osnovu sprovedene binarne logističke regresije (Tabela 4), rezultati istraživanja su pokazali da kvalitetan dizajn web sajta značajno utiče na poboljšanje imidža agencije, dok sadržaj web sajta agencije nema značajan uticaj na poslovni imidž. S tim

Tabela 3 Analiza uticaja kvaliteta web sajta agencija na odluku kupaca da preporuče usluge agencije drugima

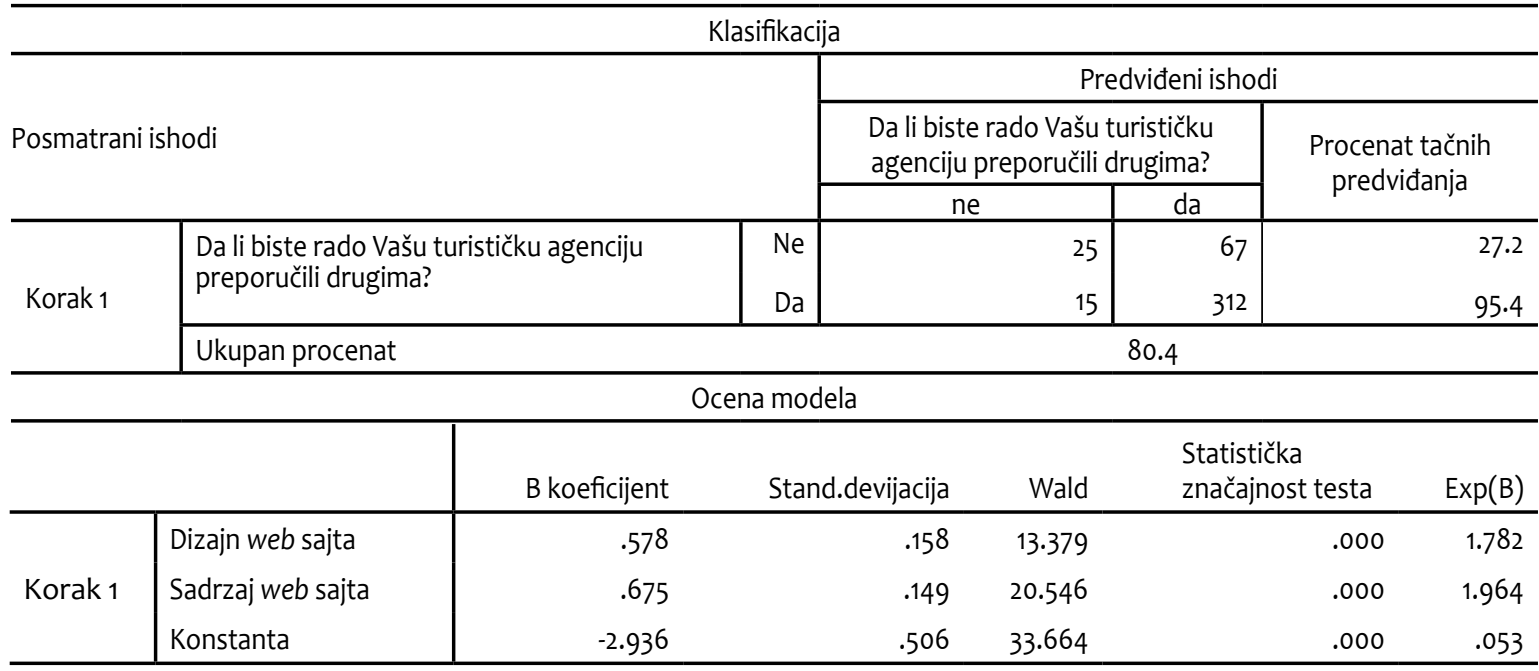

Izvor: Autor

Tabela 4 Analiza uticaja nivoa kvaliteta web sajta agencija na poslovni imidž

\begin{tabular}{|c|c|c|c|c|c|c|c|}
\hline \multicolumn{8}{|c|}{ Klasifikacija } \\
\hline \multirow{6}{*}{ Korak 1} & \multirow{3}{*}{\multicolumn{2}{|c|}{ Posmatrani ishodi }} & \multicolumn{5}{|c|}{ Predviđeni ishodi } \\
\hline & & & \multicolumn{2}{|c|}{ Imidž agencije } & & \multirow{2}{*}{$\begin{array}{l}\text { Procenat } \\
\text { tačnosti }\end{array}$} & \\
\hline & & & 1.00 & 2.00 & & & \\
\hline & \multirow{2}{*}{ Imidž agencije } & 1.00 & 27 & 60 & & & 31.0 \\
\hline & & 2.00 & 13 & 291 & & & 95.7 \\
\hline & \multicolumn{5}{|l|}{ Ukupan procenat } & & 81.3 \\
\hline \multicolumn{8}{|c|}{ Ocena modela } \\
\hline & & \multicolumn{2}{|c|}{ B koeficijent } & Stand.devijacija & Wald & $\begin{array}{l}\text { Statistička } \\
\text { značajnost testa }\end{array}$ & $\operatorname{Exp}(B)$ \\
\hline \multirow{3}{*}{ Korak 1} & Dizajn web sajta & \multicolumn{2}{|r|}{.926} & .167 & 30.645 & .000 & 2.525 \\
\hline & Sadržaj web sajta & \multicolumn{2}{|r|}{.066} & .142 & .215 & .643 & 1.068 \\
\hline & Konsanta & \multicolumn{2}{|r|}{-2.131} & .489 & 18.958 & .000 & .119 \\
\hline
\end{tabular}

Izvor: Autor

u vezi, pojedini autori (Chaffey et al, 2000) su ukazali

i na vezu između online i offline imidža preduzeća.

Odnosno, primena informacione tehnologije $u$ preduzeću omogućava personalizaciju i individualni tretman za korisnike usluga, raspoloživost informacija uz minimalne troškove traganja za informacijama, jednostavnost obavljanja transakcija putem interneta, udobnost, jednostavnost, ali i uživanje, što dovodi do povećanja nivoa satisfakcije i lojalnosti online korisnika, a indirektno i do povećanja njihovog 
poverenja u tradicionalan način kupovine. Dosadašnja istraživanja $\mathrm{u}$ turizmu nisu ukazala na pozitivan uticaj online satisfakcije korisnika na nivo poverenja koji oni imaju u tradicionalan način kupovine paket aranžmana (Álvarez et al, 2007). To je zbog toga što se $\mathrm{u}$ tradicionalnom (offline) poslovanju, nivo poverenja izgrađuje na osnovu ličnih odnosa i kontakta sa zaposlenima $\mathrm{u}$ agenciji. Klijenti koji pretražuju, rezervišu i kupuju ponude putem interneta retko se odlučuju da lično posete agenciju, tako da se sa povećanjem nivoa poverenja $\mathrm{u}$ online transakcije smanjuje stepen poverenja klijenata $u$ tradicionalan način poslovanja agencija. To je još jedan razlog zbog čega se turističke agencije odlučuju da posluju i na tradicionalan način (putem poslovnica) i putem interneta. Određeni broj korisnika želi da pretražuje putem interneta, ali zbog finansijske sigurnosti kupovinu obavlja na tradicionalan način, ličnim odlaskom $\mathrm{u}$ agenciju.

\section{ZAKLJUČAK}

Primena interneta u turističkom poslovanju omogućava pružanje individualnih usluga i specijalnog tretmana korisnicima, ali indirektno utiče i na povećanje tradicionalnog načina kupovine aranžmana. Turističke agencije ulaze $\mathrm{u}$ online poslovanje $\mathrm{i}$ konkurišu virtuelnim agencijama, na taj način što smanjuju nivo neizvesnosti prilikom obavljanja online kupovine i povećavaju nivo poverenja kod klijenata.

Rezultati istraživanja u radu su pokazali da se poslovni uspeh turističkih agencija bazira na kombinovanom tradicionalnom i online pristupu. Na osnovu testiranja polaznih pretpostavki $\mathrm{u}$ radu, potvrđeno je da online ponuda turističkih agencija predstavlja značajan faktor povećanja stepena lojalnosti kupaca i poboljšanja imidža agencija. Pri tom, dizajn i sadržaj web sajta turističkih agencija u značajnoj meri utiču na odluku kupaca da ponovo koriste usluge iste agencije, dok sadržaj web sajta nema značajan uticajna odluku kupaca da preporuče usluge agencije drugima. Za razliku od dizajna web sajta agencija, viši kvalitet web sadržaja ne utiče na poboljšanje imidža agencije. Međutim, u radu se ne analiziraju druge dimenzije online kvaliteta usluga koje mogu značajno da utiču na povećanje stepena lojalnosti korisnika turističkih usluga, što može biti predmet budućeg istraživanja. U izgradnji kvalitetnih odnosa između preduzeća i korisnika usluga potrebno je uzeti u razmatranje i druge faktore, kao na primer: nivo poverenja i privrženosti korisnika, stepen kompetentnosti zaposlenih i način njihove komunikacije sa korisnicima, proces rešavanja žalbi kupaca $\mathrm{u}$ agencijama i sl. Takođe, predmet posebnog ispitivanja može biti i primena online poslovanja $\mathrm{u}$ drugim turističkim preduzećima i uticaj online ponude na unapređenje ukupnih poslovnih performansi.

Naučni doprinos rada se ogleda u činjenici da je dokazana značajna primena kombinovanog pristupa tradicionalnog i online poslovanja agencija u unapređenju marketinških performansi. Praktični doprinos rada odnosi se na mogućnost korišćenja rezultata istraživanja $\mathrm{u}$ izgradnji kvalitetnijih odnosa sa kupcima $u$ agencijama $u$ Republici Srbiji. Može se zaključiti da online poslovanje omogućava, kako turističkim agencijama tako i ostalim učesnicima $\mathrm{u}$ turističkom lancu ponude, ostvarivanje konkurentske prednosti i izlazak na međunarodno turističko tržište.

\section{REFERENCE}

Agag, G., \& El-Masry, A. (2016). Why do consumer trust online travel websites? Drivers and outcomes of consumer trust toward online travel websites. Journal of Travel Research, 27, 1-23. doi: $10.1177 / 0047287516643185$

Álvarez, L., Martín, A., \& Casielles, R. (2007). Relationship marketing and information and communication technologies: Analysis of retail travel agencies. Journal of Travel Research, 45(4), 453-463. doi:10.1177/0047287507299593

Bilgihan, A., Okumus, F., Nusair, K., \& Kwun, D. (2011). Information technology applications and competitive advantageinhotel companies. Journal of Hospitalityand Tourism Technology, 2(2), 139-154. doi.org/10.1108/17579881111154245

Buhalis, D., \& Law, R. (2008). Progress in information technology and tourism management: 20 years on and 10 years after Internet-The state of e-Tourism research. Tourism Management, 29, 609-623. doi:10.1016/j.tourman.2008.01.005

Chaffey, D., Mayer, R., Johnston K., \& Ellis-Chadwick, F. (2000). Internet Marketing. London, UK: Prentice Hall. 
Chen, C., \& Kao, Y. (2010) Relationships between process quality, outcome quality, satisfaction, and behavioural intentions for online travel agencies - Eevidence from Taiwan. The Service Industries Journal, 30(12), 2081-2092. doi: 10.1080/02642060903191108

Chiam, M., Soutar, G., \& Yeo, A. (2009). Offline and online travel packages preferences: A conjoint analysis. International Journal of Tourism Research, 11, 31-40. doi: 10.1002/jtr.679

Dedeke, A. (2016). Travel web-site design: Information task-fit, service quality and purchase intention. Tourism Management, 54, 541-554. doi: 10.1016/j.tourman.2016.01.001

Elliott, R., \& Boshoff, C. (2009). The marketing of tourism services using the internet: A resource-based view. South Africa of Journal Business Management, 40(3), 35-49.

Ho, C., \& Lee, Y. (2007). The development of an e-travel service quality scale. Tourism Management, 28(6), 1434-1449. doi:10.1016/j.tourman.2006.12.002

Hussein, R., Ennew, C., \& Kortam, W. (2012). The adoption of web-based marketing in the travel and tourism industry: An empirical investigation in Egypt. Journal of Innovation Management in Small \& Medium Enterprises, 1-23. doi: $10.5171 / 2012.143325$

Kim, J., Jin, B., \& Swinney, J. (2009). The role of retail quality, e-satisfaction and e-trust in online loyalty development process. Journal of Retailing and Consumer Services, 16(4), 239247. doi: 10.1016/j.jretconser.2008.11.019

Koi-Akrofi, G., Koi-Akrofi, J., \& Welbeck, J. (2013). Relationship marketing tactics and customer loyalty-a case of the mobile telecommunication industry in Ghana. Asian Journal of Business Management 5(1), 77-92.

Liu, Z., Park. S. (2015). What makes a useful online review? Implication for travel product websites. Tourism Management, 47, 140-151. doi.org/10.1016/j.tourman.2014.09.020

Mamaghani, M. (2009). Impact of e-commerce on travel and tourism: An historical analysis. International Journal of Management, 26(3), 365-375.

Middleton, V., Fyall, A., Morgan, M., \& Ranchhod, A. (2009). Marketing in travel and tourism. Oxford, UK: Elsevier.
Mihajlović, I. (2012). The Impact of information and communication technology (ICT) as a key factor of tourism development on the role of Croatian travel agencies. International Journal of Business and Social Science, 3(24), 151-159.

Ndubisi, N. (2007). Relationship marketing and customer loyalty. Marketing Intelligence and Planning, 25(1), 98-106. doi. org/10.1108/02634500710722425

Ngai, E. W. T. (2005). Customer relationship management research (1992-2002), an academic literature review and classification. Marketing Intelligence \& Planning, 23(6), 582605. doi.org/10.1108/02634500510624147

Nusair, K. (2008). Business-to-customer relationship marketing for travel industry. Saarbrucken, Germany: Verlag Dr. Muller.

Nusair, K., Parsa, H., \& Cobanoglu, C. (2011). Building a model of commitment for Generation Y: An empirical study on e-travel retailers. Tourism Management, 32(4), 833-843. doi. org/10.1016/j.tourman.2010.07.008

Phillips, P., Barners, S., Zigan, K., Schegg, R. (2016). Understanding the impact of online reviews on hotel performance: An empirical analysis. Journal of Travel Research, 27, 1-15. doi: 10.1177/0047287516636481

Radosavljević, G. (2009). Menadžment u turizmu. Kragujevac, Rweb Srbija: Ekonomski fakultet Univrziteta u Kragujevcu.

Radosavljević, G., Maksimović, Lj., \& Borisavljević, K. (2012). Customer satisfaction with online offer of tourist agencies in Serbia. Actual Problems of Economics, 11(137), 436-448.

Siegel, C. (2004). Internet marketing: foundations and applications. Boston, USA: Houghton Miffin Company.

Thao, H., \& Swierczek, F. (2008). Internet use, customer relationships and loyalty in the Vietnamese travel industry. Asia Pacific Journal of Marketing and Logistics, 20(2), 190-210. doi.org/10.1108/13555850810864551

Unković, S. i Zečević, B. (2013). Ekonomika turizma. Beograd, Rweb Srbija: Ekonomski fakultet Univerziteta u Beogradu.

Yoo, W., Lee, Y., \& Park, J. (2010). The role of interactivity in e-tailing: Creating value and increasing satisfaction. Journal of Retailing and Consumer Services, 17(2), 89-96. doi:10.1016/j. jretconser.2009.10.003
Primljeno 09. novembra 2016, nakon revizije, prihvaćeno za publikovanje 26. decembra 2016. Elektronska verzija objavljena 30. decembra 2016. 
Katarina Borisavljević je asistent na Ekonomskom fakultetu Univerziteta u Kragujevcu, na nastavnim predmetima: Menadžment $\mathrm{u}$ turizmu i hotelijerstvu i Ekonomika i organizacija trgovinskih preduzeća. Doktorirala je na Ekonomskom fakultetu Univerziteta u Beogradu iz oblasti turizma. Ključne oblasti njenog naučnoistraživačkog interesovanja su marketing i menadžment $u$ turizmu i upravljanje kanalima marketinga.

\title{
THE INFLUENCE OF INFORMATION TECHNOLOGY ON MARKETING PERFORMANCES OF TOURIST AGENCIES
}

\author{
Katarina Borisavljevic \\ University of Kragujevac, Faculty of Economics, Kragujevac,The Republic of Serbia
}

\begin{abstract}
The implementation of information technology in tourism brings numerous advantages for all participants in the chain of the tourism offer. Traditional tourist agencies also orient themselves towards online business doing via the Internet. On the other hand, the Internet has an influence on the reduction in the mediation role of tourist agencies. The subject matter of the research done in this paper is the implementation of the Internet in the business doing of tourist agencies with the aim to improve their marketing performances. The aim of the research is the influence of the quality of the Internet offer of tourist agencies on the development of the relationships with buyers and the improvement of the image of tourist agencies operating in the Republic of Serbia. The research results presented in the paper have shown that a higher level of the quality of agencies' Internet offer has a positive influence on buyer loyalty, as well as on the image of an agency. The business success of tourist agencies is based on a combined approach of traditional and online business doing.
\end{abstract}

Keywords: tourist agency, Internet, business image, buyer loyalty

JEL Classification: M15, M31, Z30 